\title{
Observed changes in precipitation totals in Poland
}

\author{
IWONA PIŃSKWAR ${ }^{1}$, ADAM CHORYŃSKI ${ }^{1}$, DARIUSZ GRACZYK ${ }^{1}$, \\ ZBIGNIEW W. KUNDZEWICZ ${ }^{1,2}$
}

1 Polish Academy of Sciences, Institute for Agricultural and Forest Environment, Poznań, Poland; e-mail: iwona.pinskwar@isrl.poznan.pl

2 Potsdam Institute for Climate Impact Research, Potsdam, Germany

ABSTRACT This paper examines observed changes in the indices of mean precipitation in Poland, based on daily precipitation records for 45 stations in Poland from 1961 to 2017. Changes in annual, semi-annual, seasonal, as well as monthly precipitation totals are examined. In addition, changes in the number of days with precipitation $(\geq 1 \mathrm{~mm})$, as well as in the Simple Daily Intensity Index and the ratio of precipitation in the warm half-year to precipitation in the cold half-year are studied. Many changes are detected, but most of them are not statistically significant at the 0.1 level. Yet, there are regionally consistent seasonal changes, with a dominating clear precipitation increase in spring and winter. The Student's t-test for the comparison of means for two intervals: 1961-1990 and 1991-2017 revealed statistically significant increases for annual and spring precipitation, as well as for Simple Daily Intensity Index, and monthly data: increases for February, March, July, September, October and decreases for: June, August, November, December.

KEY WORDS mean precipitation - precipitation change - trend analysis - histogram - Poland

PIŃSKWAR, I., CHORYŃSKI, A., GRACZYK, D., KUNDZEWICZ, Z.W. (2019): Observed changes in precipitation totals in Poland. Geografie, 124, 3, 237-264.

Received May 2018, accepted April 2019.

C Česká geografická společnost, z. s., 2019 


\section{Introduction}

Mean annual precipitation total for Poland based on data for 1961-2009 amounts to $623.7 \mathrm{~mm}$ (Wibig, Jakusik 2012). In lowlands and highlands, which cover most of the country, mean annual precipitation ranges from above 500 to $700 \mathrm{~mm}$. Higher values occur in the southern part of Poland, in the mountainous area. Freshwater resources in Poland, calculated per inhabitant, are among the smallest in Europe (GUS 2016), therefore every change in precipitation has an impact on different sectors of human activity in the country, including agriculture, energy production and industry. Kovats et al. (2014) note that changes in annual precipitation since 1950 include increases in Northern Europe (up to $+70 \mathrm{~mm}$ per decade) and decreases in parts of Southern Europe. The change of annual precipitation in Poland is less pronounced there. Also Becker et al. (2013) pointed on the general northsouth gradient of trends (wetter/drier) across Europe, but for the mid-latitudes there is a high variability of trends among stations, due to the natural variability and local factors. These findings are consistent with trends in annual precipitation across Europe between 1960 and 2015 reported by EEA (2017), i.e. decreasing trend for annual precipitation in south-eastern part of Poland and an increasing trend in the northern and eastern parts of the country. Changes in mean precipitation and their distribution in particular months are especially important for crops cultivation and ecosystems. Changes in annual precipitation total give an information about magnitude of precipitation and changes in number of days with daily sum of precipitation equal or greater than $1 \mathrm{~mm}$, i.e. frequency of the precipitation. Intensity of precipitation, expressed by the Simple Daily Intensity Index (SDII) is also important. Increase in annual precipitation total and decrease in the number of days with precipitation during the year results in SDII increase, which has an adverse impact on the rainfall distribution and could lead to inundation and flooding. Even if SDII is mostly used as an index of extreme precipitation, it also carries information about mean intensity (Zhang et al. 2011).

Analysis of precipitation total remain in the field of interest of many scientists. The number of indices used and their different definitions are large and depend on aim of the study. Especially, extreme values of precipitation sum are important. Precipitation totals are often examined with different types of circulations or precipitable water capacity (Degirmendžić, Kożuchowski 2017) or with temperature and evapotranspiration in the cause of problems with scarcity of water or droughts (Somorowska, 2016). The highest values of precipitation total in annual, seasonal or monthly scales often coincide with inundation and flooding, like during 1970, 1977, 1997, 2001, 2010 or 2017 in Poland (Kundzewicz et al. 2012; Konieczny, Pińskwar, Kundzewicz 2018). During last years Europe, and also Poland, is facing with shortages of water and droughts strengthened additionally by high temperatures. Among years with droughts: 2003, 2006, 2010, 2015 and 
2018, especially the last two were extremely severe. During August 2015 on the River Vistula the lowest stage since records began in the eighteenth century was observed. Many rivers reached the lowest values of the stages (and discharges) since the 1950s (Somorowska 2016). Drought of 2018 begun in spring, because monthly precipitation totals were much below the mean values and anomalies of temperature were high, so these dry conditions have been not improved even higher than normal monthly totals for July, which were recorded on many station, in this in Poznań, where nearly all sum cumulated in one decade (IMGW 2018). Rulfová and Kyselý (2014) detected increasing trends in convective precipitation, stronger than trends in stratiform precipitation, during three seasons: spring, summer and autumn over 1982-2010. According to the mentioned authors, increases in total precipitation are mainly due to increases in convective precipitation, accelerated by increases in surface air temperature. This can lead to both longer periods without precipitation and occurrence of more extreme precipitation. Numerous studies on extreme precipitation show that there are many more significant increasing trends than significant decreasing trends (Donat et al. 2013; Westra, Alexander, Zwiers 2013; Łupikasza 2017; Pińskwar et al. 2019).

Another important issue are changes in the interannual cycle of precipitation. One of indices characterizing this interannual cycle is the ratio of precipitation total during the warm season (Apr.-Sept.) to precipitation total in the preceding cold season (Oct.-March). This index is very important especially from agricultural point of view. In Polish conditions, it is disadvantageous that precipitation total from October to March increases and precipitation total from April to September decreases or else - the increase during the warm season is smaller than during the cold season. It will result in problems related to low water storage, due to lack of vegetation and faster surface runoff and could lead to spring droughts (Kędziora et al. 2014; Czarnecka, Nidzgorska-Lencewicz 2012).

The paper analyses changes in annual, seasonal and monthly precipitation totals. Detecting changes in precipitation total for annual and seasonal scale are very important, but equally important are also analyses of changes for months. Changes in monthly total of precipitation show which months have an impact on seasonal precipitation changes. Sometimes one month with higher changes contributes to changes observed during particular seasons (more drier or more wetter) and the signs of changes may differs from month to month (Mager, Kasprowicz, Farat 2009; Świątek 2011; Zeleňáková et al. 2016; Jaagus et al. 2018). Detecting changes in precipitation total at the regional scale is an important issue and should be a repeatable task. This is done in the present research and updates earlier studies carried out in Poland by extending time series of observations to the year 2017. In many earlier studies (Degirmendžić, Kożuchowski Żmudzka 2004; Mager, Kasprowicz, Farat 2009; Kożuchowski 2004; Świątek 2011; Czarnecka, Nidzgorska-Lencewicz 2012; Kaźmierczak, Kotowski, Wdowikowski 2014; Degirmendžić, Kożuchowski 
2017; Tomczyk, Szyga-Pluta 2018), time series of observation records extending to the first years of the $21^{\text {th }}$ century were used.

\section{Data and methods}

Precipitation datasets used in this study were provided by the Institute of Meteorology and Water Management - State Research Institute (IMGW-PIB) and have been processed. Table 1 shows a list of 45 stations and basic characteristics of precipitation at these stations (mean annual precipitation for time intervals 1961-1990 and 1991-2017, as well as minimum and maximum values of annual precipitation totals with year of the occurrence).

Table 1 - List of meteorological stations with precipitation data used in this research and characteristics of annual precipitation (mean for 1961-1990 and 1991-2017, as well as minimum and maximum values with the year of occurrence)

\begin{tabular}{|c|c|c|c|c|c|c|c|}
\hline \multirow[t]{2}{*}{ Station } & \multirow{2}{*}{$\begin{array}{c}\text { Elevation } \mathrm{H} \\
\text { (m a.s.l.) }\end{array}$} & \multicolumn{6}{|c|}{ Annual precipitation total (mm) } \\
\hline & & $\begin{array}{c}\text { Mean } \\
1961-1990\end{array}$ & $\begin{array}{c}\text { Mean } \\
1991-2017\end{array}$ & Min & Year & $\operatorname{Max}$ & Year \\
\hline Białystok & 148 & 591 & 612 & 446 & 1971 & 935 & 2017 \\
\hline Bielsko-Biała & 398 & 991 & 995 & 739 & 1993 & 1,505 & 1966 \\
\hline Chojnice & 172 & 558 & 616 & 312 & 1982 & 835 & 2007 \\
\hline Gorzów Wielkopolski & 72 & 554 & 563 & 335 & 1982 & 872 & 2017 \\
\hline Hel & 1 & 572 & 609 & 345 & 1975 & 837 & 1970 \\
\hline Jelenia Góra & 342 & 689 & 719 & 462 & 1990 & 1,005 & 1977 \\
\hline Kalisz & 140 & 508 & 500 & 259 & 2015 & 721 & 1981 \\
\hline Kasprowy Wierch & 1,991 & 1,826 & 1,762 & 1,292 & 1993 & 2,600 & 2001 \\
\hline Katowice & 280 & 722 & 725 & 489 & 2015 & 1,011 & 1974 \\
\hline Kielce-Suków & 268 & 632 & 636 & 439 & 1982 & 1,000 & 1966 \\
\hline Kłodzko & 356 & 594 & 598 & 339 & 2015 & 845 & 2010 \\
\hline Koło & 116 & 518 & 534 & 307 & 1989 & 794 & 1966 \\
\hline Kołobrzeg & 3 & 663 & 715 & 437 & 1975 & 899 & 2017 \\
\hline Koszalin & 33 & 704 & 752 & 481 & 1982 & 1,013 & 2007 \\
\hline Legnica & 122 & 545 & 528 & 361 & 2003 & 795 & 1977 \\
\hline Lesko & 386 & 801 & 838 & 447 & 1961 & 1,104 & 2010 \\
\hline Leszno & 91 & 543 & 559 & 348 & 1982 & 748 & 2016 \\
\hline Lublin & 238 & 582 & 605 & 368 & 1982 & 846 & 1974 \\
\hline Łeba & 2 & 651 & 670 & 420 & 1964 & 997 & 1970 \\
\hline Łódź & 187 & 578 & 586 & 400 & 2015 & 832 & 2017 \\
\hline Mława & 147 & 551 & 565 & 355 & 1971 & 860 & 2017 \\
\hline Nowy Sącz & 292 & 721 & 738 & 512 & 1986 & 1,155 & 2010 \\
\hline Olsztyn & 133 & 637 & 643 & 403 & 1982 & 973 & 2017 \\
\hline Opole & 176 & 637 & 587 & 364 & 2015 & 868 & 2010 \\
\hline Płock & 106 & 543 & 527 & 319 & 2015 & 821 & 1970 \\
\hline
\end{tabular}




\begin{tabular}{|c|c|c|c|c|c|c|c|}
\hline \multirow[t]{2}{*}{ Station } & \multirow{2}{*}{$\begin{array}{l}\text { Elevation } \mathrm{H} \\
\text { (m a.s.l.) }\end{array}$} & \multicolumn{6}{|c|}{ Annual precipitation total (mm) } \\
\hline & & $\begin{array}{c}\text { Mean } \\
1961-1990\end{array}$ & $\begin{array}{c}\text { Mean } \\
1991-2017\end{array}$ & Min & Year & Max & Year \\
\hline Poznań & 86 & 515 & 552 & 275 & 1982 & 772 & 1967 \\
\hline Racibórz & 190 & 650 & 604 & 278 & 2015 & 1,001 & 1977 \\
\hline Rzeszów & 200 & 625 & 664 & 381 & 1982 & 1,009 & 1966 \\
\hline Sandomierz & 217 & 567 & 556 & 378 & 1973 & 860 & 1966 \\
\hline Siedlce & 146 & 532 & 556 & 394 & 1991 & 738 & 2010 \\
\hline Stubice & 21 & 552 & 572 & 361 & 1991 & 861 & 2010 \\
\hline Suwałki & 184 & 592 & 615 & 390 & 1976 & 856 & 2017 \\
\hline Szczecin-Dąbie & 1 & 527 & 581 & 349 & 1982 & 840 & 2017 \\
\hline Śnieżka & 1,603 & 1,266 & 1,097 & 756 & 2003 & 1,908 & 1977 \\
\hline Świnoujście & 6 & 543 & 598 & 386 & 1982 & 783 & 2017 \\
\hline Tarnów & 209 & 723 & 732 & 462 & 1982 & 1,216 & 2010 \\
\hline Terespol & 133 & 518 & 541 & 335 & 1991 & 777 & 1974 \\
\hline Toruń & 69 & 533 & 553 & 310 & 1989 & 843 & 1980 \\
\hline Ustka & 6 & 713 & 678 & 467 & 1975 & 1,019 & 1970 \\
\hline Warszawa & 106 & 516 & 556 & 358 & 1976 & 796 & 2010 \\
\hline Wieluń & 195 & 605 & 599 & 366 & 2015 & 926 & 1974 \\
\hline Włodawa & 175 & 534 & 560 & 383 & 1969 & 872 & 1974 \\
\hline Wroctaw & 120 & 588 & 543 & 381 & 1982 & 776 & 1977 \\
\hline Zakopane & 857 & 1,125 & 1,149 & 811 & 1993 & 1,645 & 2010 \\
\hline Zielona Góra & 180 & 582 & 600 & 385 & 1982 & 807 & 2017 \\
\hline
\end{tabular}

Datasets are complete without missing data. Monthly totals were examined by three tests of homogeneity: Mann-Whitney-Pettitt test, Penalized maximum t-test and the Standard Normal Homogeneity test (SNH), using the AnClim software (Štěpánek 2008). Verification of data homogeneity poses difficulties because of strong natural variability of precipitation. According to results of these three tests for each series, data from 43 out of 45 were classified as "useful" (if the number of tests rejecting the null hypothesis about homogeneity at the $5 \%$ level is not greater than one) and two (Racibórz and Śnieżka) as "suspect" (where two or three tests reject the null hypothesis). Additionally, data from Racibórz were tested by SNHT for two series with respect to a neighbouring, sufficiently correlated homogeneous station. This test did not reject the null hypothesis. The approach is considered to be more powerful than tests, which use only a single series (Wijngaard et al. 2003). Śnieżka is one of the two mountainous stations, included by WMO to Global Atmosphere Watch - Stations, so that despite the test results, data were used. Figure 1 shows the spatial coverage of precipitation data for Poland used in this paper.

Based on the data, values of the following indices related to precipitation were calculated:

- annual precipitation totals 
- number of wet days with daily precipitation $\geq 1 \mathrm{~mm}$

- Simple Daily Intensity Index SDII - the ratio of annual total precipitation to the number of days during the year with daily precipitation $\geq 1 \mathrm{~mm}$

- relation of precipitation total in the warm season (Apr.-Sept.) to precipitation total in the preceding cold season (Oct.-March)

- precipitation total for the cold half-year (Oct.-March) and the warm half-year (Apr.-Sept.)

- precipitation sums in particular seasons - winter: Dec.-Feb. (DJF); spring: March-May (MAM); summer: June-Aug. (JJA) and autumn: Sept.-Nov. (SON) and individual months.

In this research, in order to show changes of every examined index, mean values for 1991-2017 and the WMO climate standard normal period 1961-1990 have been compared. Changes are calculated in relative (percentage) terms. Trends for the whole period, 1961-2017, have been tested with the Mann-Kendall test and identified as statistically significant when significance level (SL) was equal to or less than 0.1. Additionally, histograms with fitted log-normal distribution for these two periods: 1961-1990 and 1991-2017 have been compared, based on the values of indices for 40 stations (with mean annual precipitation below $800 \mathrm{~mm}$ for the period 1961-1990), i.e. records at five stations: Bielsko-Biała, Lesko, Kasprowy Wierch, Śnieżka and Zakopane, were not used (see Table 1). Also the Student's
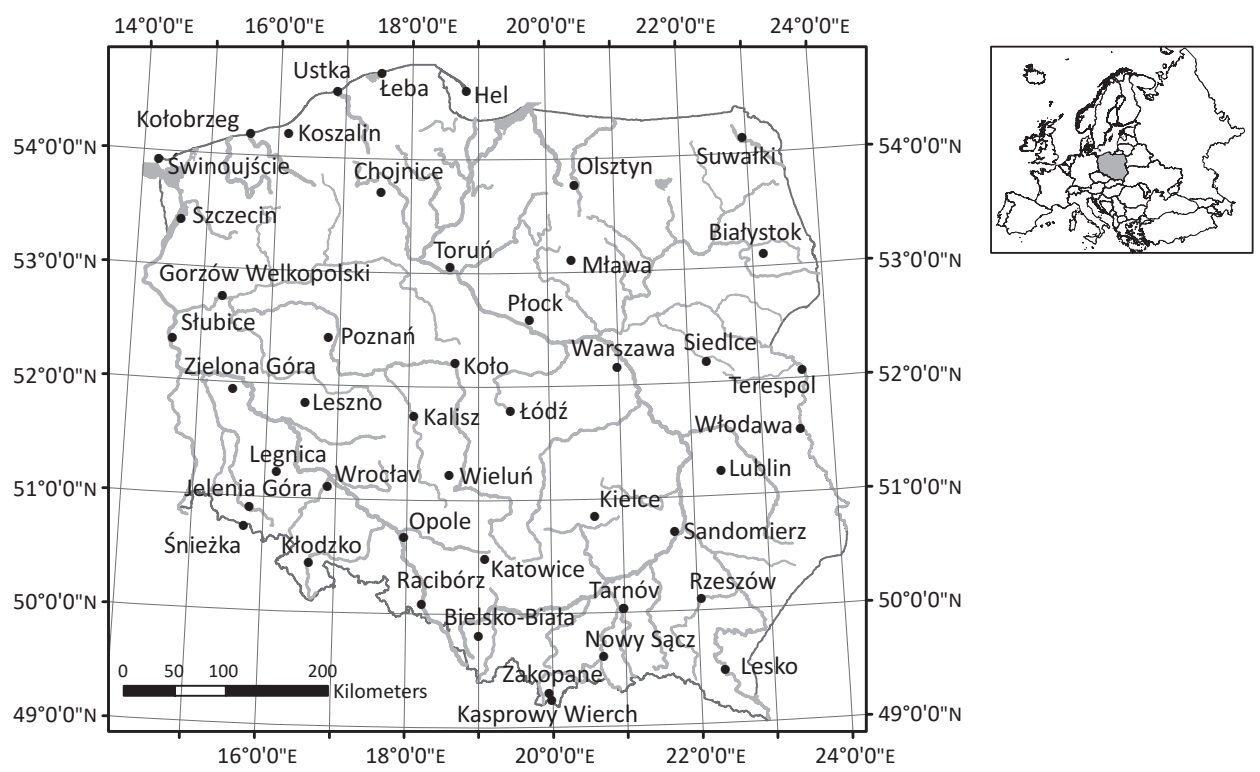

Fig. 1 - Location of stations in Poland with precipitation data used in this study 
t-test for the comparison of two means has been used and such statistics as: median and quartiles have been calculated.

\section{Changes in precipitation totals}

\subsection{Annual and semi-annual time scale}

The highest number of annual minimum precipitation records in a single year from this dataset occurred in 1982 (fourteen stations), and then in 2015 (eight stations). Year 2015, with severe drought, brought a new record for the lowest annual precipitation: $259 \mathrm{~mm}$ in Kalisz, merely $51 \%$ of mean annual precipitation for 1961-1990. By this time, the lowest annual precipitation was recorded in Poznań: $275 \mathrm{~mm}$ in 1982.

Most of maximum annual precipitation records occurred in 2017 (10 stations), then in 2010 (the year with large floods, in which records were broken at eight stations). The highest annual precipitation totals in this dataset were observed at the mountainous stations Kasprowy Wierch (1,991 $\mathrm{m}$ a.s.1.): 2,600 $\mathrm{mm}$ in 2001 and Śnieżka (1,603 $\mathrm{m}$ a.s.1.): 1,908 $\mathrm{mm}$ in 1977, then at the Zakopane station (857 $\mathrm{m}$ a.s.l.): $1,645 \mathrm{~mm}$ in 2010 .

The comparison of annual precipitation between 1961-1990 and 1991-2017 (Fig. 2a) shows an increase for 34 out of 45 stations. For 25 stations it was lower than $5 \%$ and for nine stations it was higher than $5 \%$. It can be noticed that northern, central and south-eastern parts of Poland became more humid, and four changes

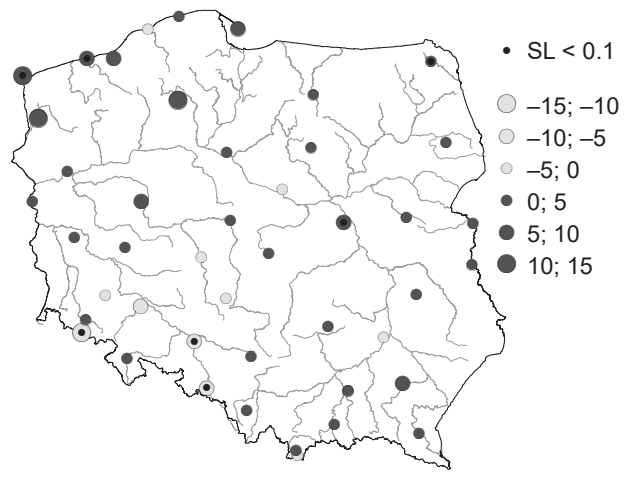

(a) Annual precipitation - percentage change

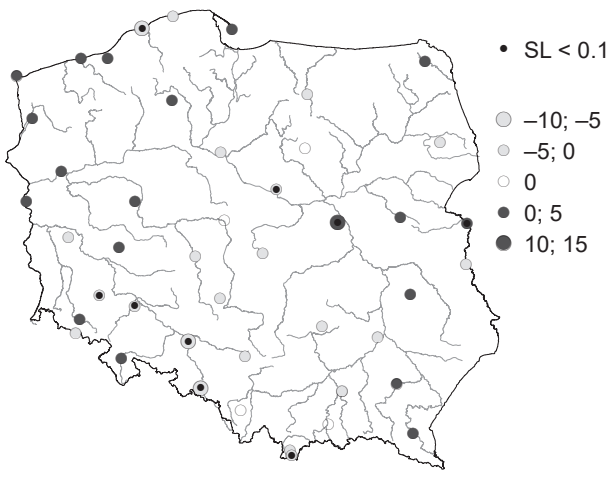

(b) No. of days with precipitation $\geq 1 \mathrm{~mm}$ percentage change

Fig. 2 - Relative change of mean annual precipitation (a) and change in the mean number of wet days with precipitation equal to or greater than $1 \mathrm{~mm}$ (b). Changes were calculated between the interval 1991-2017 and 1961-1990. The black dots show significant change $(\mathrm{SL}<0.1)$. 
Table 2 - Number of stations with direction of changes, mean percentage change for all stations (mean for the interval 1991-2017 vs 1961-1990) and statistics: mean for 40 stations (with mean annual precipitation total below $800 \mathrm{~mm}$ ) as well as median and quartiles for two intervals: 1961-1990 and 1991-2017. Statistically significant changes in mean are marked in gray, the higher values of statistics (in italic).

\begin{tabular}{|c|c|c|c|c|c|c|c|}
\hline \multirow[t]{2}{*}{ Index } & \multirow{2}{*}{$\begin{array}{l}\text { No. of } \\
\text { stations } \\
\text { with } \\
\text { increase } \\
\text { (with } \\
S L<0.1 \text { ) }\end{array}$} & \multirow{2}{*}{$\begin{array}{l}\text { No. of } \\
\text { stations } \\
\text { with } \\
\text { decrease } \\
\text { (with } \\
S L<0.1 \text { ) }\end{array}$} & \multirow{2}{*}{$\begin{array}{c}\text { Mean change } \\
\text { and the } \\
\text { range (5\%; } \\
95 \%) \text { for } \\
\text { all stations } \\
(\%)\end{array}$} & \multicolumn{2}{|c|}{$\begin{array}{l}\text { Mean for } 40 \text { stations } \\
\text { (mm; day) }\end{array}$} & \multicolumn{2}{|c|}{$\begin{array}{l}\text { Median for } 40 \text { stations } \\
(25 \% ; 75 \%) \\
(\mathrm{mm} ; \text { day })\end{array}$} \\
\hline & & & & 1961-1990 & 1991-2017 & 1961-1990 & $1991-2017$ \\
\hline $\begin{array}{l}\text { Annual precipitation } \\
\text { total }\end{array}$ & $34(4)$ & $11(3)$ & $\begin{array}{c}1.9 \\
(-7.6 ; 9.6)\end{array}$ & 592.1 & 606.5 & $\begin{array}{c}581 \\
(500 ; 670)\end{array}$ & $\begin{array}{c}594 \\
(524 ; 681)\end{array}$ \\
\hline $\begin{array}{l}\text { No. of wet days with } \\
P \geq 1 \mathrm{~mm}\end{array}$ & $19(2)$ & $22(7)$ & $\begin{array}{c}-0.3 \\
(-6.3 ; 3.7)\end{array}$ & 104.8 & 104.7 & $\begin{array}{c}104 \\
(93 ; 116)\end{array}$ & $\begin{array}{c}105 \\
(94 ; 114)\end{array}$ \\
\hline SDII & $39(6)$ & $6(1)$ & $\begin{array}{c}2.5 \\
(-1.2 ; 7.7)\end{array}$ & 5.4 & 5.5 & $\begin{array}{c}5.3 \\
(4.9 ; 5.9)\end{array}$ & $\begin{array}{c}5.5 \\
(5.0 ; 6.0)\end{array}$ \\
\hline $\begin{array}{l}\text { Ratio of precipitation } \\
\text { totals (Apr.-Sept. to } \\
\text { Oct.-March) }\end{array}$ & $16(1)$ & $29(2)$ & $\begin{array}{c}-1.9 \\
(-13.1 ; 10.2)\end{array}$ & 1.83 & 1.79 & $\begin{array}{c}1.7 \\
(1.3 ; 2.2)\end{array}$ & $\begin{array}{c}1.6 \\
(1.3 ; 2.1)\end{array}$ \\
\hline $\begin{array}{l}\text { Precipitation total for } \\
\text { cold half year } \\
\text { (Oct.-March) }\end{array}$ & $30(3)$ & $15(4)$ & $\begin{array}{c}1.5 \\
(-10.0 ; 9.7)\end{array}$ & 223.0 & 226.9 & $\begin{array}{c}214 \\
(169 ; 264)\end{array}$ & $\begin{array}{c}222 \\
(184 ; 267)\end{array}$ \\
\hline $\begin{array}{l}\text { Precipitation total } \\
\text { for warm half year } \\
\text { (Apr.-Sept.) }\end{array}$ & $30(1)$ & $15(1)$ & $\begin{array}{c}1.3 \\
(-7.1 ; 9.0)\end{array}$ & 370.2 & 377.3 & $\begin{array}{c}364 \\
(300 ; 428)\end{array}$ & $\begin{array}{c}369 \\
(309 ; 436)\end{array}$ \\
\hline $\begin{array}{l}\text { Precipitation total } \\
\text { for Winter (DJF) }\end{array}$ & $28(8)$ & $17(4)$ & $\begin{array}{c}2.1 \\
(-15.4 ; 16.3)\end{array}$ & 101.4 & 104.2 & $\begin{array}{c}98 \\
(74 ; 124)\end{array}$ & $\begin{array}{c}102 \\
(79 ; 125)\end{array}$ \\
\hline $\begin{array}{l}\text { Precipitation total } \\
\text { for Spring (MAM) }\end{array}$ & $32(2)$ & $13(4)$ & $\begin{array}{c}5.4 \\
(-9.8 ; 17.7)\end{array}$ & 127.9 & 136.0 & $\begin{array}{c}122 \\
(96 ; 152)\end{array}$ & $\begin{array}{c}132 \\
(106 ; 159)\end{array}$ \\
\hline $\begin{array}{l}\text { Precipitation total } \\
\text { for Summer (JJA) }\end{array}$ & $19(7)$ & $26(1)$ & $\begin{array}{c}-0.2 \\
(-10.3 ; 12.7)\end{array}$ & 221.4 & 222.5 & $\begin{array}{c}214 \\
(167 ; 267)\end{array}$ & $\begin{array}{c}217 \\
(169 ; 269)\end{array}$ \\
\hline $\begin{array}{l}\text { Precipitation total } \\
\text { for Autumn (SON) }\end{array}$ & $26(0)$ & $19(0)$ & $\begin{array}{c}2.2 \\
(-7.7 ; 16.4)\end{array}$ & 141.7 & 143.5 & $\begin{array}{c}134 \\
(100 ; 171)\end{array}$ & $\begin{array}{c}136 \\
(107 ; 175)\end{array}$ \\
\hline $\begin{array}{l}\text { Precipitation total } \\
\text { for January }\end{array}$ & $35(8)$ & $10(0)$ & $\begin{array}{c}9.2 \\
(-12.6 ; 24.0)\end{array}$ & 32.6 & 35.5 & $\begin{array}{c}29 \\
(18 ; 43)\end{array}$ & $\begin{array}{c}33 \\
(22 ; 46)\end{array}$ \\
\hline $\begin{array}{l}\text { Precipitation total } \\
\text { for February }\end{array}$ & $36(4)$ & $9(1)$ & $\begin{array}{c}12.1 \\
(-15.6 ; 33.1)\end{array}$ & 27.5 & 31.0 & $\begin{array}{c}26 \\
(15 ; 37)\end{array}$ & $\begin{array}{c}30 \\
(21 ; 40)\end{array}$ \\
\hline $\begin{array}{l}\text { Precipitation total } \\
\text { for March }\end{array}$ & $42(6)$ & $3(0)$ & $\begin{array}{c}21.9 \\
(-2.1 ; 43.1)\end{array}$ & 30.8 & 37.7 & $\begin{array}{c}29 \\
(19 ; 40)\end{array}$ & $\begin{array}{c}35 \\
(23 ; 49)\end{array}$ \\
\hline $\begin{array}{l}\text { Precipitation total } \\
\text { for April }\end{array}$ & $21(0)$ & $24(4)$ & $\begin{array}{c}-4.4 \\
(-26.4 ; 12.7)\end{array}$ & 38.3 & 37.0 & $\begin{array}{c}35 \\
(23 ; 50)\end{array}$ & $\begin{array}{c}33 \\
(21 ; 49)\end{array}$ \\
\hline $\begin{array}{l}\text { Precipitation total } \\
\text { for May }\end{array}$ & $31(1)$ & $14(5)$ & $\begin{array}{c}4.1 \\
(-13.8 ; 22.5)\end{array}$ & 58.8 & 61.4 & $\begin{array}{c}54 \\
(37 ; 76)\end{array}$ & $\begin{array}{c}56 \\
(38 ; 79)\end{array}$ \\
\hline $\begin{array}{l}\text { Precipitation total } \\
\text { for June }\end{array}$ & $11(3)$ & $34(4)$ & $\begin{array}{c}-6.8 \\
(-21.6 ; 14.8)\end{array}$ & 72.2 & 67.6 & $\begin{array}{c}66 \\
(45 ; 95)\end{array}$ & $\begin{array}{c}63 \\
(40 ; 88)\end{array}$ \\
\hline
\end{tabular}




\begin{tabular}{|c|c|c|c|c|c|c|c|}
\hline \multirow[t]{2}{*}{ Index } & \multirow{2}{*}{$\begin{array}{c}\text { No. of } \\
\text { stations } \\
\text { with } \\
\text { increase } \\
\text { (with } \\
\mathrm{SL}<0.1 \text { ) }\end{array}$} & \multirow{2}{*}{$\begin{array}{l}\text { No. of } \\
\text { stations } \\
\text { with } \\
\text { decrease } \\
\text { (with } \\
\text { SL }<0.1 \text { ) }\end{array}$} & \multirow{2}{*}{$\begin{array}{l}\text { Mean change } \\
\text { and the } \\
\text { range (5\%; } \\
95 \%) \text { for } \\
\text { all stations } \\
(\%)\end{array}$} & \multicolumn{2}{|c|}{$\begin{array}{l}\text { Mean for } 40 \text { stations } \\
\text { (mm; day) }\end{array}$} & \multicolumn{2}{|c|}{$\begin{array}{c}\text { Median for } 40 \text { stations } \\
(25 \% ; 75 \%) \\
(\mathrm{mm} ; \text { day })\end{array}$} \\
\hline & & & & 1961-1990 & $1991-2017$ & 1961-1990 & 1991-2017 \\
\hline $\begin{array}{l}\text { Precipitation total } \\
\text { for July }\end{array}$ & $41(8)$ & $4(0)$ & $\begin{array}{c}13.2 \\
(-8.1 ; 38.7)\end{array}$ & 78.4 & 87.8 & $\begin{array}{c}73 \\
(47 ; 102)\end{array}$ & $\begin{array}{c}78 \\
(49 ; 114)\end{array}$ \\
\hline $\begin{array}{l}\text { Precipitation total } \\
\text { for August }\end{array}$ & $15(1)$ & $30(6)$ & $\begin{array}{c}-5.7 \\
(-28.2 ; 22.0)\end{array}$ & 70.8 & 67.1 & $\begin{array}{c}64 \\
(43 ; 89)\end{array}$ & $\begin{array}{c}59 \\
(41 ; 87)\end{array}$ \\
\hline $\begin{array}{l}\text { Precipitation total } \\
\text { for September }\end{array}$ & $39(2)$ & $6(1)$ & $\begin{array}{c}10.9 \\
(-4.2 ; 34.2)\end{array}$ & 51.6 & 56.5 & $\begin{array}{c}48 \\
(30 ; 67)\end{array}$ & $\begin{array}{c}49 \\
(30 ; 77)\end{array}$ \\
\hline $\begin{array}{l}\text { Precipitation total } \\
\text { for October }\end{array}$ & $32(0)$ & $12(0)$ & $\begin{array}{c}7.1 \\
(-9.6 ; 23.2)\end{array}$ & 43.1 & 45.9 & $\begin{array}{c}34 \\
(20 ; 55)\end{array}$ & $\begin{array}{c}39 \\
(23 ; 63)\end{array}$ \\
\hline $\begin{array}{l}\text { Precipitation total } \\
\text { for November }\end{array}$ & $2(0)$ & $43(16)$ & $\begin{array}{c}-11.9 \\
(-22.3 ;-4.1)\end{array}$ & 47.0 & 41.1 & $\begin{array}{c}42 \\
(31 ; 59)\end{array}$ & $\begin{array}{c}38 \\
(27 ; 52)\end{array}$ \\
\hline $\begin{array}{l}\text { Precipitation total } \\
\text { for December }\end{array}$ & $12(0)$ & $33(10)$ & $\begin{array}{c}-8.2 \\
(-27.2 ; 11.2)\end{array}$ & 40.9 & 38.1 & $\begin{array}{c}39 \\
(26 ; 54)\end{array}$ & $\begin{array}{c}35 \\
(23 ; 49)\end{array}$ \\
\hline
\end{tabular}

are statistically significant at the 0.1 level. Three downward changes are significant and found in the south of Poland. The mean precipitation, areally averaged over Poland, increased by $1.9 \%$ (see Table 2).

For the number of wet days with precipitation ( $\geq 1 \mathrm{~mm}$; Fig. $2 \mathrm{~b}$ ), decrease is noted at nearly half of 45 stations (seven changes were statistically significant). For four stations, the number of wet days did not change. More wet days are observed at 19 stations (in this two statistically significant changes). The mean change in the number of wet days is $-0.3 \%$ (Table 2 ).

Histograms for annual precipitation at stations (with mean annual precipitation below $800 \mathrm{~mm}$ for the period 1961-1990) revealed that during last 27 warmer years (1991-2017) there were less annual precipitation totals below $550 \mathrm{~mm}$ and more annual totals above $550 \mathrm{~mm}$. The highest frequency was observed for the range 550-600 mm, while in the period 1961-1990 the highest frequency was for the range $500-550 \mathrm{~mm}$ (see Fig. 3a). The median and quartiles were higher for annual precipitation totals from interval 1991-2017 in comparison with 1961-1990 and the changes in means were statistically significant (see Table 2). During period 1991-2017, the number of wet days was higher in classes from 90 to 120 and lower in other classes, so that the first quartile and median were higher, but third quartile was lower, in comparison to 1961-1990 (Table 2).

The value of SDII depends on annual precipitation total and annual numbers of wet days, therefore, changes of these indices affect changes of SDII. The SDII has increased (Fig. 4a) in the last 27 years (1991-2017), as compared to the interval 1961-90 for a large area of Poland: for 39 out of 45 stations, and six of these 

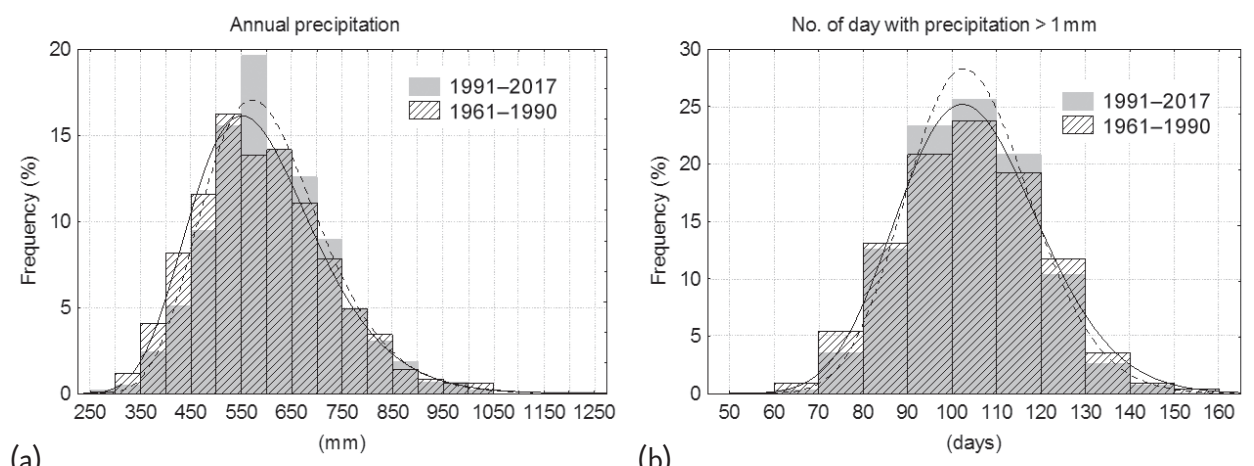

Fig. 3 - Histograms with fitted log-normal distribution for 40 stations for two periods: 1961-1990 and 1991-2017 of annual precipitation (a) and the number of wet days with precipitation equal to or greater than $1 \mathrm{~mm}$ (b). The solid line represents log-normal distribution for 1961-1990 and dotted for 1991-2017.

changes are statistically significant. Only for one station decrease is statistically significant (Fig. 4a). The mean change for all stations is increasing: $2.5 \%$ (see Table 2).

One can draw a conclusion that increase in the annual precipitation total is due to an increase of the amount of precipitation during wet days. This can be stated with confidence for such stations as: Białystok, Bielsko-Biała, Katowice, Kielce, Koło, Łeba, Łódź, Mława, Nowy Sącz, Olsztyn, Tarnów, Toruń, Włodawa, Zakopane and Zielona Góra. For these 15 stations, the mean annual precipitation

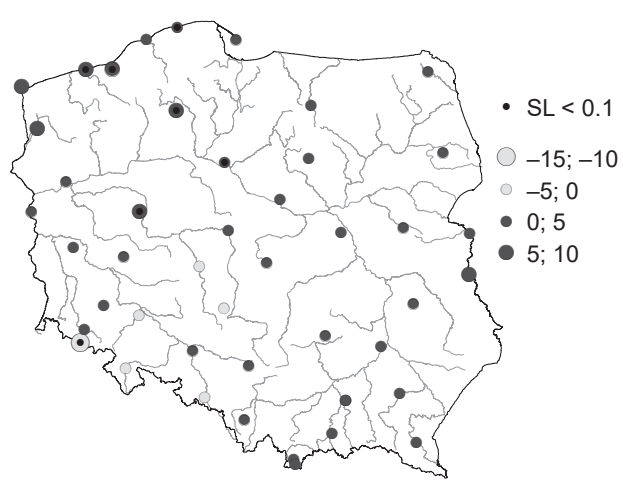

(a) SDII - percentage change

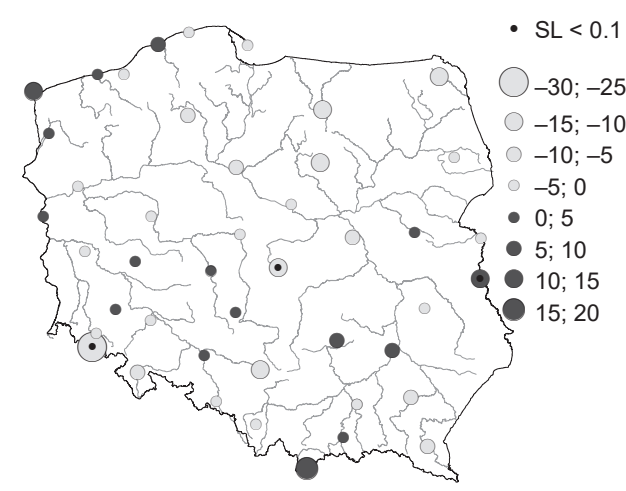

(b) The ratio of sum of precipitation percentage change

Fig. 4 - Relative change of Simple Daily Intensity Index SDII (a) and the ratio of precipitation total in the warm season (Apr.-Sept.) to precipitation total in the cold season (Oct.-March - b - mean for the interval 1991-2017 related to the mean for 1961-1990. Black dots show a significant change $(\mathrm{SL}<0.1)$. 

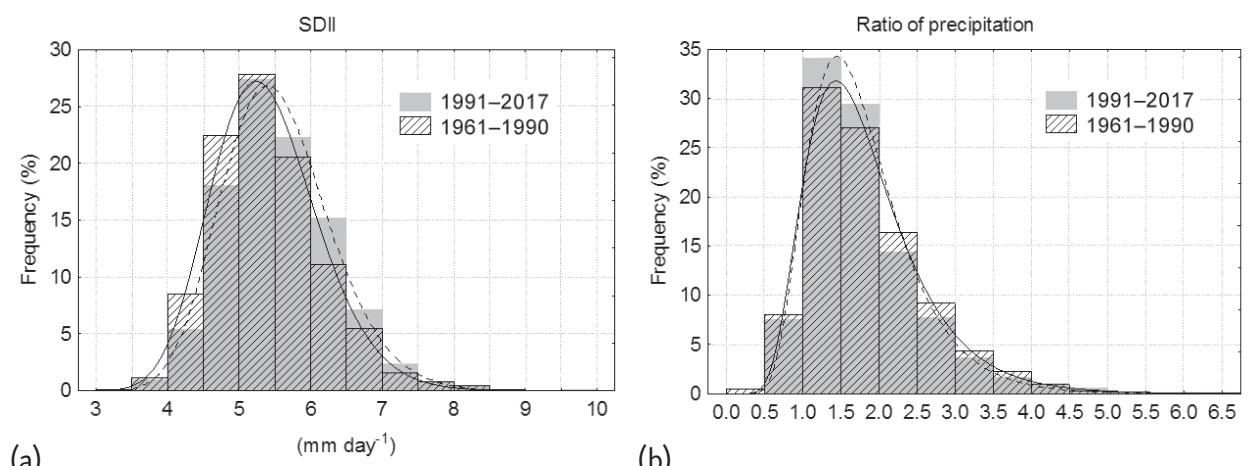

(a)

Fig. 5 - Histograms with fitted log-normal distribution for 40 stations for two periods: 1961-1990 and 1991-2017 of SDII (a) and the ratio of precipitation totals in the warm season (Apr.-Sept.) to precipitation total in the preceding cold season (Oct.-March - b). The solid line represents log-normal distribution for the interval: 1961-1990 and dotted - for 1991-2017.

is higher for the last 27 years (1991-2017) while the mean number of wet days with precipitation ( $\geq 1 \mathrm{~mm}$ ) was lower than the previous mean calculated for 1961-1990 or remained unchanged.

The ratio of precipitation total in the warm season (Apr.-Sept.) to precipitation total in the cold season (Oct.-March) shows a decreasing trend for 29 stations (Fig. 4b) and decrease of this index is larger than increase for 16 other stations. However, only three changes are statistically significant: two decreases and one increase. The mean change for all stations is $-1.9 \%$.

Even if the results shown in Fig. $4 \mathrm{~b}$ are not strong, they are of considerable importance in Poland. Decrease of the ratio of precipitation in the warmer season to precipitation in the colder season is disadvantageous. This change in seasonal distribution means that much of water in the cold season runs off to the sea (all water storage reservoirs in the country can store only $6 \%$ of annual river flow), while water in the warm season can be missing for vegetation.

Histograms for two intervals: 1961-1990 and 1991-2017 for SDII (Fig. 5a) show shift in the relative frequency of intensity. There were less days with precipitation of lower intensity (especially from 4.0 to $5.0 \mathrm{~mm} \mathrm{day}^{-1}$ ) and more days with higher intensity of precipitation (greater than $5.5 \mathrm{~mm} \mathrm{day}^{-1}$ ) during the last 27 years in comparison with frequency for 1961-1990 (Fig. 5a).

The changes in means are statistically significant. Also the median and quartiles of SDII are higher for the period 1991-2017 (see Table 2). Histograms of the ratio of precipitation total in the warm season to precipitation total in the preceding cold season revealed increase in frequency in ranges from 1.0 to 2.0 and decrease in higher ranges during the interval 1991-2017 (Fig. 5b). Quartiles of this index are also lower for 1991-2017 (Table 2). 
Changes in the ratio of precipitation totals in the warm season (Apr.-Sept.) and the preceding cold season (Oct.-March) depend on changes of precipitation totals for these two parts of a year. Decrease in the ratio of precipitation may be due to an increase of precipitation total for the cold half-year or a decrease of precipitation total for the warm half-year or when increase of precipitation total for the warm half-year is smaller than increase of precipitation total for the cold half-year. Figure 6 shows precipitation totals for these two parts of the year (Oct.-March and Apr.-Sept.).

Precipitation total for the cold half-year increases at 30 stations (in this two changes being statistically significant). Decreases of this index are visible at 15 stations with four statistically significant decreases in south Poland.

Precipitation total for the warm half-year also increases at 30 stations: the most in northern part of Poland and decreases at 15 stations (in this one increase and one decrease statistically significant). The mean changes for these half-years are: $1.5 \%$ and $1.3 \%$, respectively for cold and warm half-years. Despite of increase of precipitation for the warm half-year, the ratio of precipitation decreases for 18 stations: Białystok, Chojnice, Hel, Jelenia Góra, Koło, Koszalin, Lesko, Lublin, Łeba, Poznań, Rzeszów, Suwałki, Terespol, Tarnów, Torun, Warszawa, Zakopane and Zielona Góra.

Histograms for the cold half-year (Oct.-March) for two intervals: 1961-1990 and 1991-2017 show nearly $10 \%$ increase in relative frequency in the range from 200 to $250 \mathrm{~mm}$ for last 27 years (1991-2017) and 5\% decrease in the range from 100 to $150 \mathrm{~mm}$ in comparison with the interval 1961-1990 (Fig. 7a). For the warm half-year (Apr.-Sept.), decrease in relative frequency of nearly $5 \%$ is also visible in lower range $250-300 \mathrm{~mm}$, but increases in ranges from 300 to $400 \mathrm{~mm}$ are

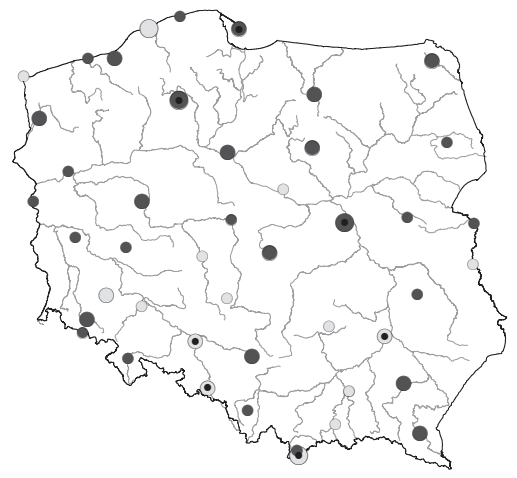

(a) Precipitation for cold half-year percentage change

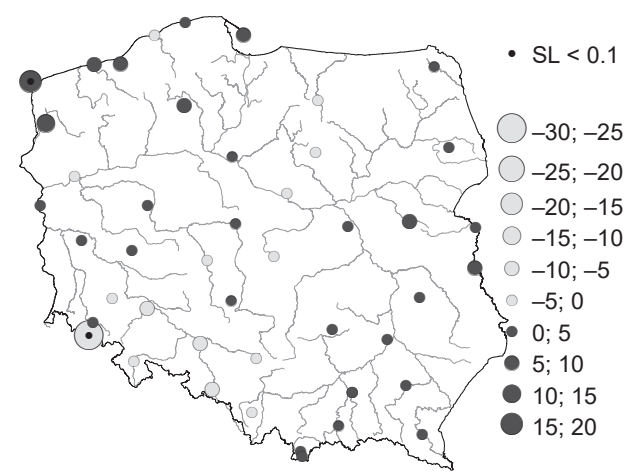

(b) Precipitation for warm half-year percentage change

Fig. 6 - Percentage change of precipitation total for the cold half-year (Oct.-March - a) and for the warm half-year (Apr.-Sept. - b). The mean for the interval 1991-2017 was related to the mean for 1961-1990. The black dots show significant change $(\mathrm{SL}<0.1)$. 

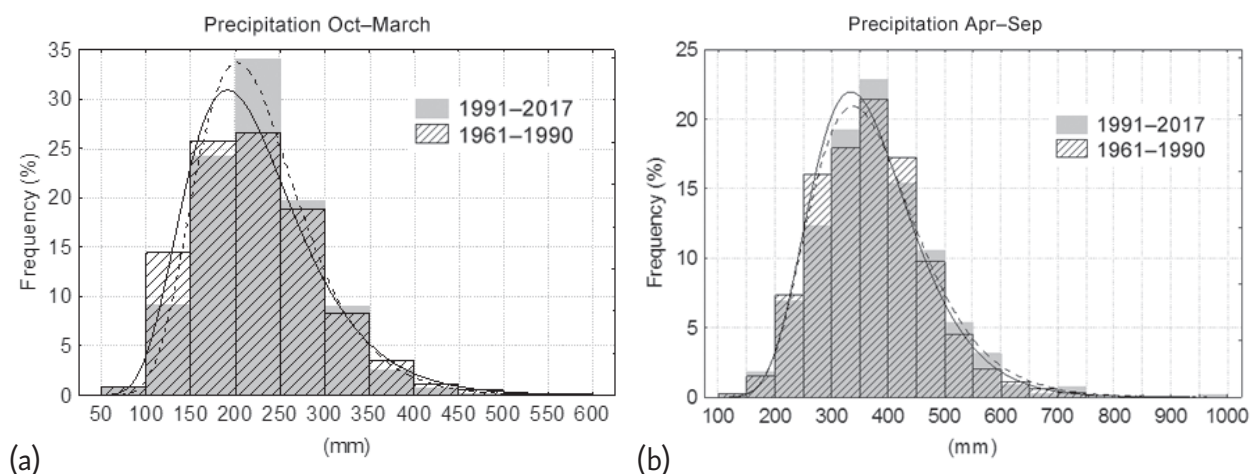

Fig. 7 - Histograms with fitted log-normal distribution for 40 stations in two periods: 1961-1990 and 1991-2017 for precipitation total in the cold half-year (Oct.-March - a) and the warm half-year (Apr.-Sept. - b). The solid line represents log-normal distribution for the first period: 1961-1990 and dotted - for 1991-2017.

less noticeable. Also small increases occurred in the range from 450 to $600 \mathrm{~mm}$ (Fig. 7b). The median and quartiles are higher for the interval 1991-2017 in comparison with the previous interval, 1961-1990, for both indices.

\subsection{Seasonal time scale}

Seasonal precipitation totals confirm the findings for half-years (Fig. 8). For central and northern part of Poland, winter (DJF) got wetter in 1991-2017, in comparison to $1961-1990$ (Fig. 8a). The number of statistically significant changes was highest for this season (12, therein eight for increases and four for decreases). The mean change for all stations is $2.1 \%$ (see Table 2).

Similarly, an increase in precipitation total is visible for spring (MAM) with six significant changes (Fig. 8b). For this season, decreases in precipitation sums are noticeable mainly in the south-western part of Poland, where three changes are statistically significant. The mean change for all stations is the highest of all seasons: $5.4 \%$ (Table 2).

Summer is getting wetter for the western and northern parts of country with seven statistically significant changes (Fig. 8c). Despite of this, decreases are prevailing and the mean change for summer is $-0.2 \%$ (Table 2 ).

Changes in precipitation sums in autumn (SON) are not statistically significant (Fig. 8d). Increases are noticeable in eastern and southern parts of Poland and the mean increase was by $2.2 \%$ (Table 2 ).

Histograms of seasonal precipitation totals, for two intervals: 1961-1990 and 1991-2017 (Fig. 9), show decreases in relative frequency for lower ranges and 


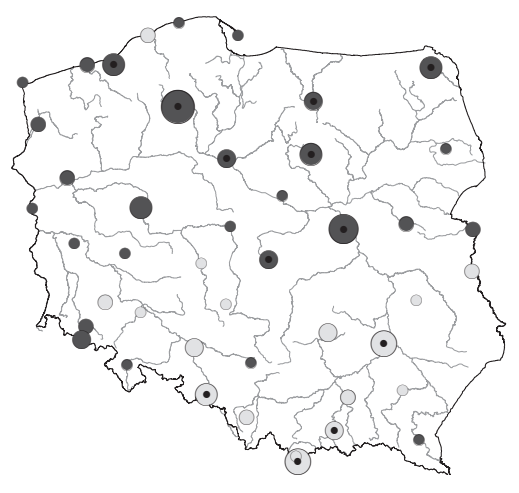

(a) Winter - percentage change

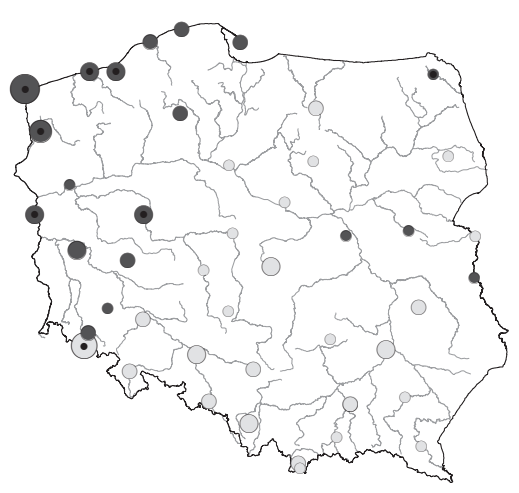

(c) Summer - percentage change

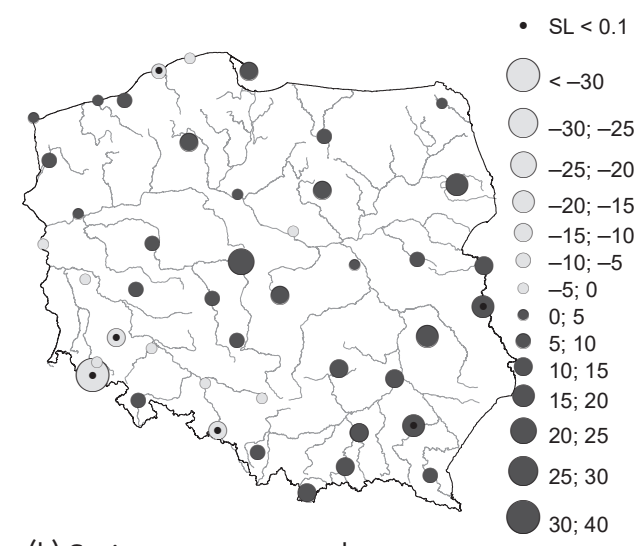

(b) Spring - percentage change

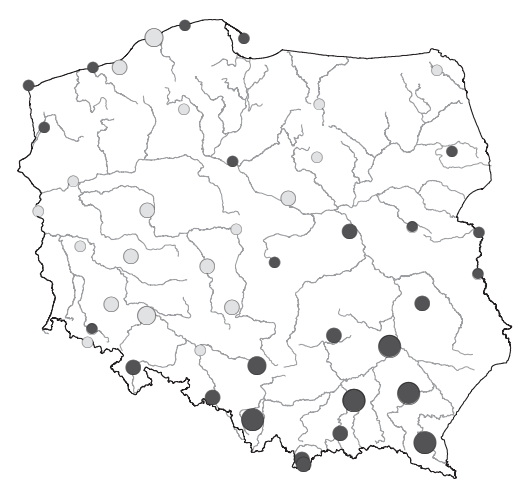

(d) Autumn - percentage change

Fig. 8 - Percentage change of precipitation total for the seasons: a - winter (DJF), b - spring (MAM), c - summer (JJA) and d - autumn (SON). The mean for the 1991-2017 interval was related to the mean for 1961-1990. The black dots show significant change $(\mathrm{SL}<0.1)$.

increases for mean and higher ranges, especially for spring and winter. The highest increase (about $3 \%$ ) in relative frequency for winter is noticed in the precipitation range from 100 to $125 \mathrm{~mm}$. For spring, there is a $5 \%$ decrease for the range $75-100 \mathrm{~mm}$ and nearly $5 \%$ increase for the ranges $125-150$ and $150-175 \mathrm{~mm}$ and about $3 \%$ for the range $175-200 \mathrm{~mm}$ (i.e. above the third quartiles: 152 and $159 \mathrm{~mm}$, respectively for both periods). The changes in means are statistically significant (see Table 2). The highest increase for summer (about 2.5\%) is for the range 300-350 mm. During autumn, there are less years with precipitation totals from 50 to $100 \mathrm{~mm}$ for the period 1991-2017 and more with precipitation totals from 100 to $150 \mathrm{~mm}$ and then $175-250 \mathrm{~mm}$. For all seasons, median, first and third quartiles are higher for the last 27 years (1991-2017; Table 2). 


\subsection{Monthly time scale}

The analyses of changes in precipitation total in particular months (Fig. 10) enable to answer the question: which months are principally contributing to seasonal precipitation changes.

In order to interpret seasonal changes in winter (Figs. 8a), one can look at changes in each of the three months - December, January, and February. Precipitation total for December is decreasing for nearly all stations located in the central and southern part of Poland (Fig. 10a) with ten statistically significant changes. The mean change for all stations is decreasing by $8.2 \%$ (see Table 2). In contrast, precipitation total for January (Fig. 10b) increases for 35 of 45 stations and eight changes are statistically significant. No decrease is statistically significant. The mean change for all stations is positive, by $9.2 \%$. Also one can note that February (Fig. 10c) is getting wetter: the mean precipitation total for the last 27 years
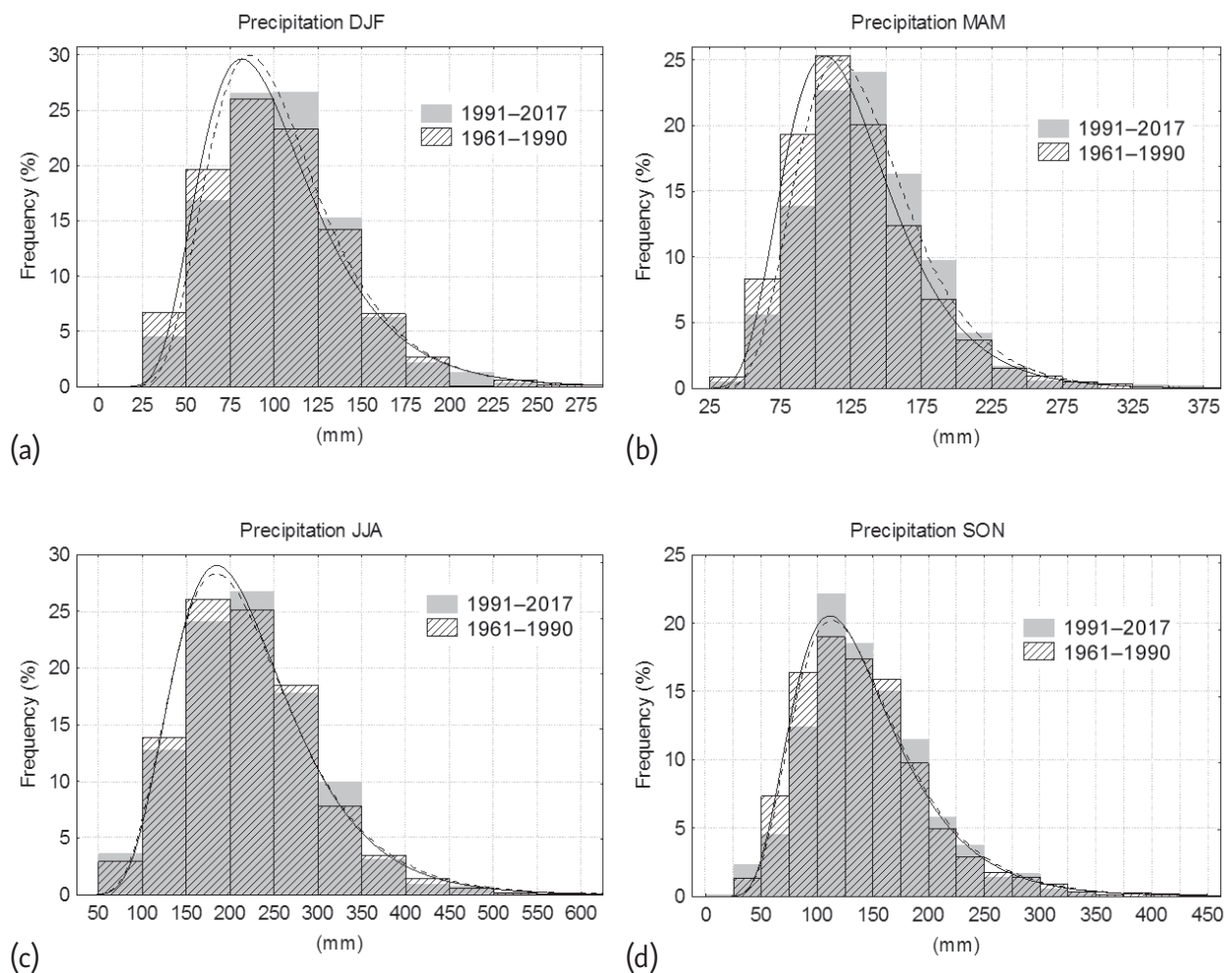

Fig. 9 - Histograms with fitted log-normal distribution of seasonal precipitation for 40 stations for two periods: 1961-1990 and 1991-2017 for: a - winter, b - spring, c - summer, d - autumn. The solid line represents log-normal distribution for the period: 1961-1990 and dotted - for 1991-2017. 


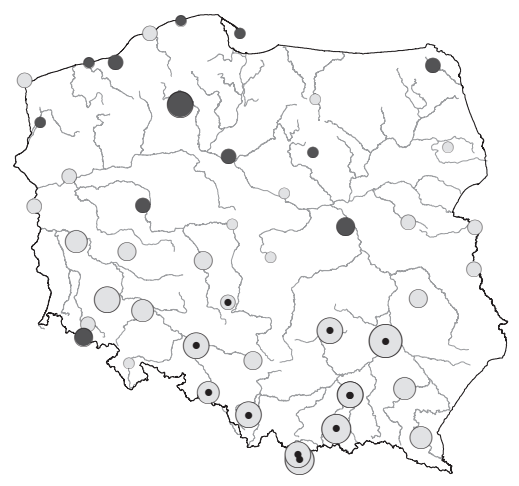

(a) December - percentage change

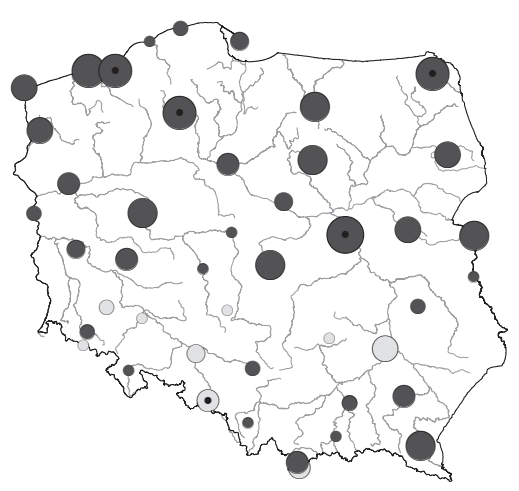

(c) February - percentage change

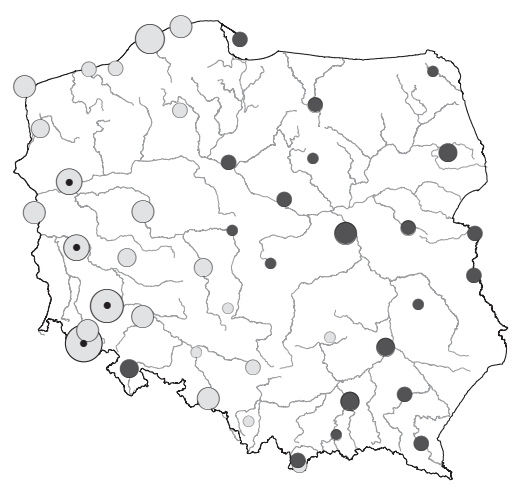

(e) April - percentage change

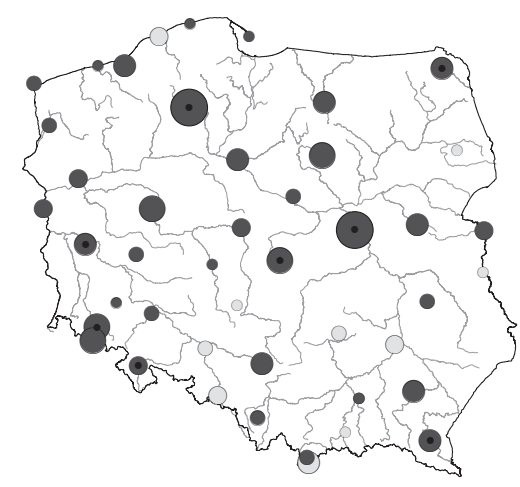

(b) January - percentage change

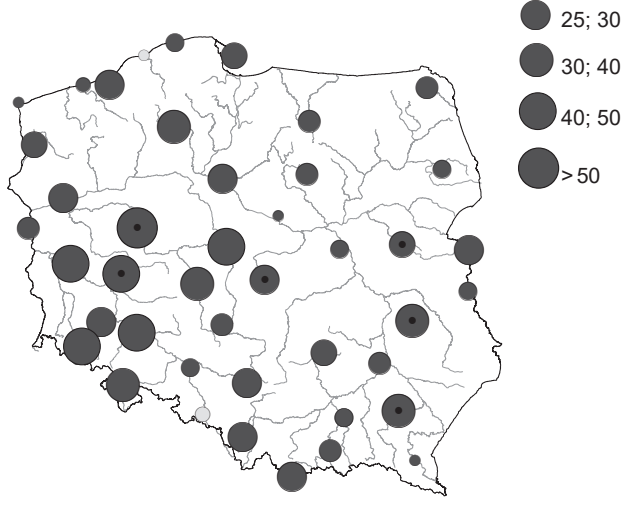

(d) March - percentage change

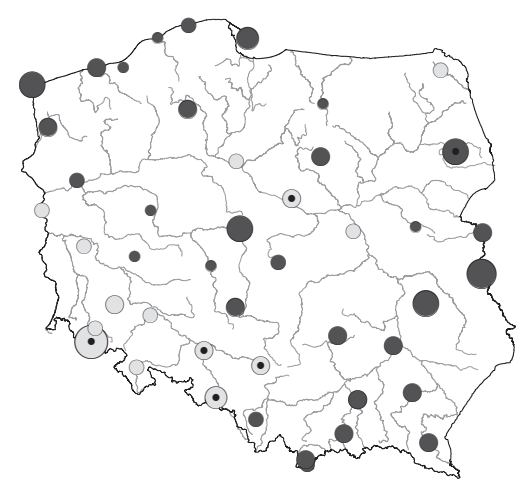

(f) May - percentage change

Fig. 10 - Percentage change of mean precipitation total for particular months in seasonal order: a-l - mean for the interval 1991-2017, related to the mean for 1961-1990. The black dots show significant change $(S L<0.1)$. Square for September means significant decrease at Mlawa (MK test), but the percentage change is positive due to anomaly high precipitation total in September 2017. 


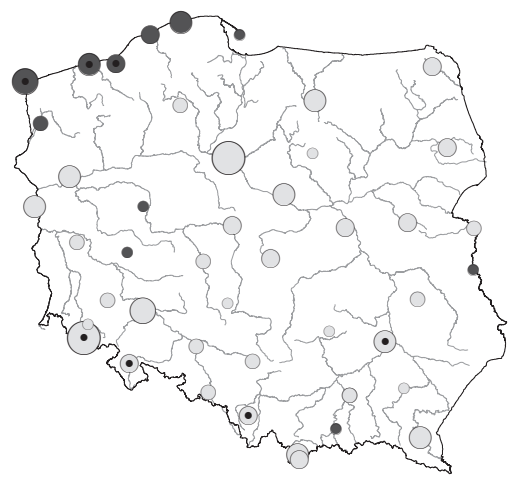

(g) June - percentage change

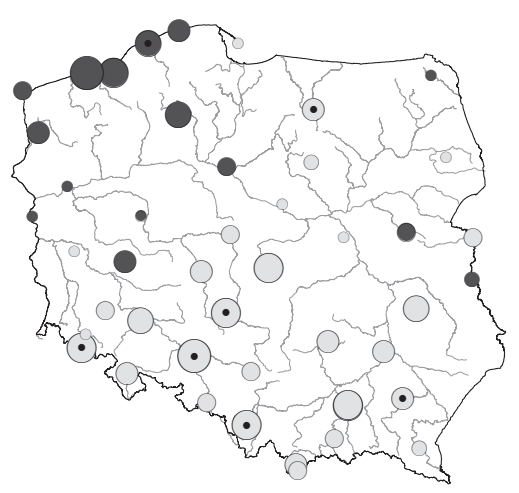

(i) August - percentage change

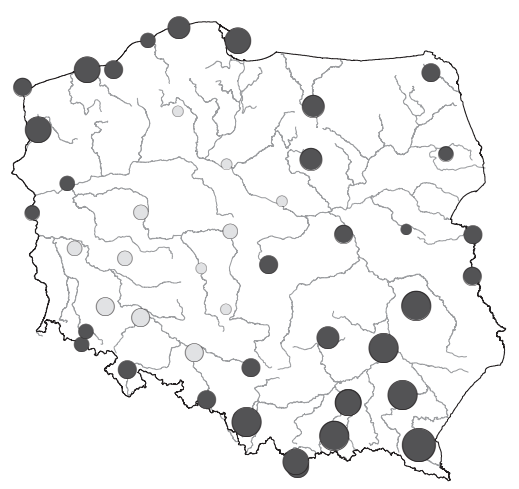

(k) October - percentage change

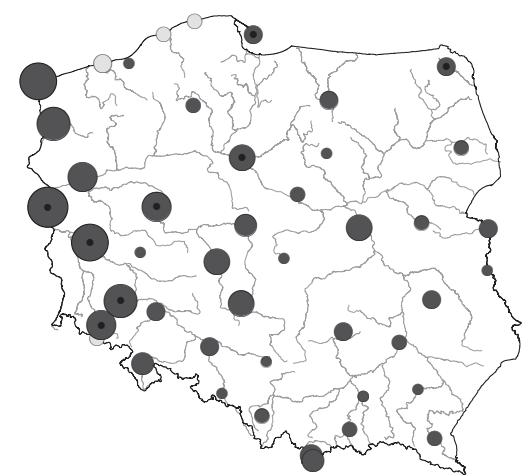

(h) July - percentage change

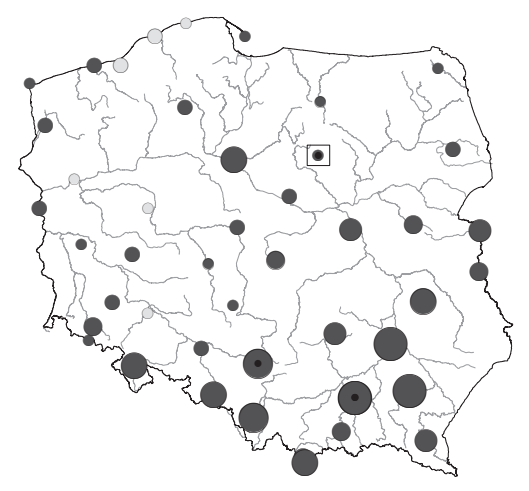

(j) September - percentage change

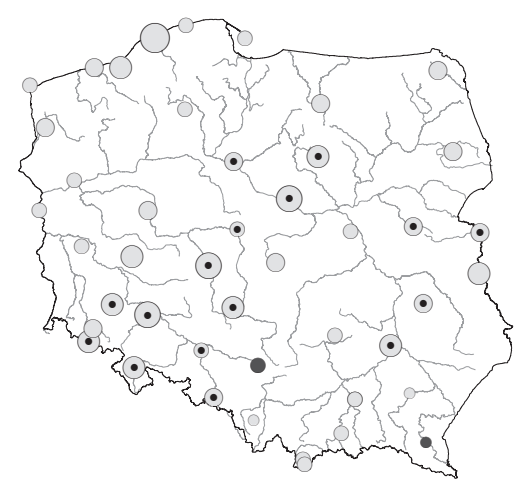

(l) November - percentage change

Fig. 10 (cont.) 

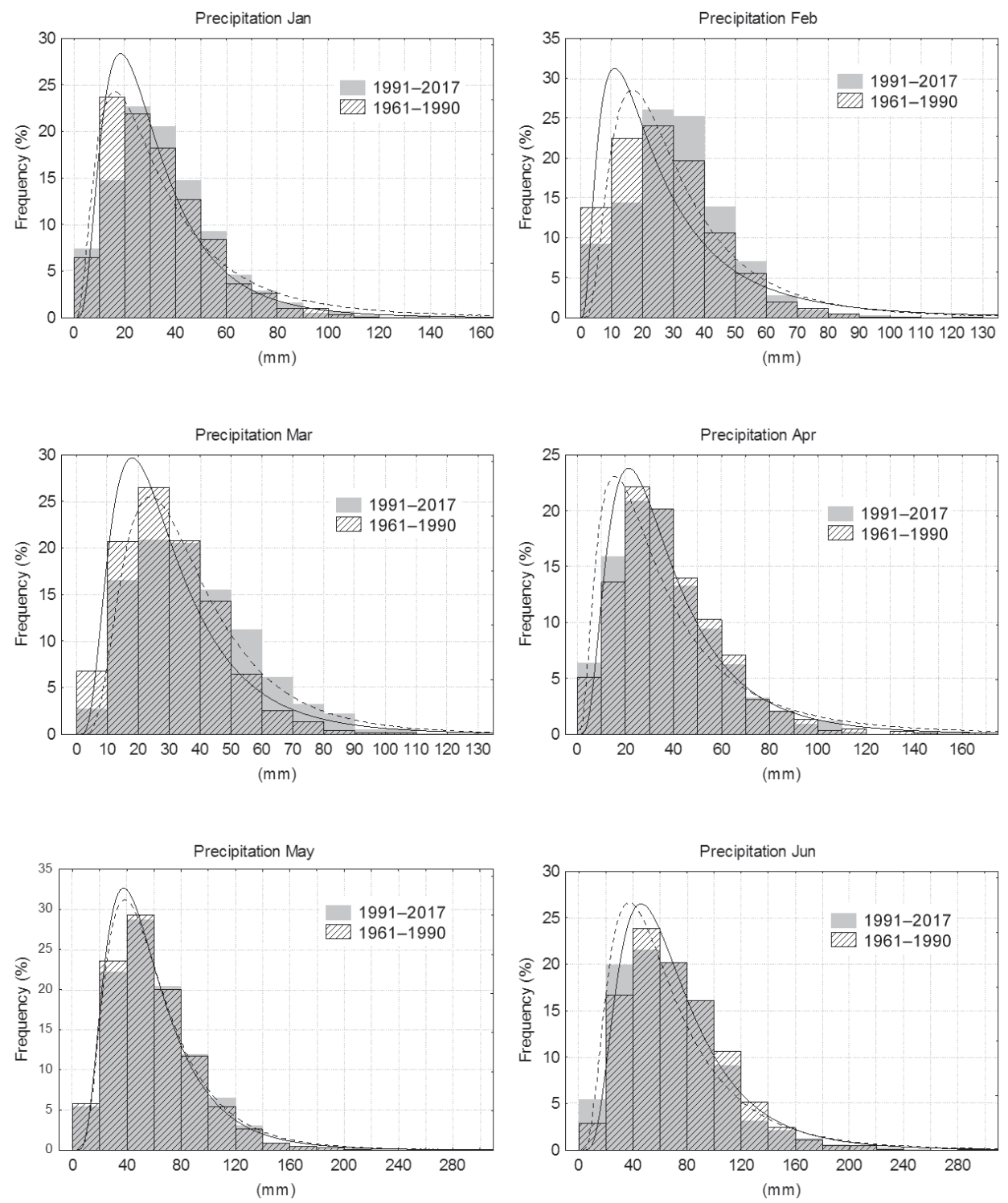

Fig. 11 - Histograms with fitted log-normal distribution for 40 stations for two periods: 1961-1990 and 1991-2017, for the precipitation totals for particular months. The solid line represents log-normal distribution for 1961-1990 and dotted - for 1991-2017. 

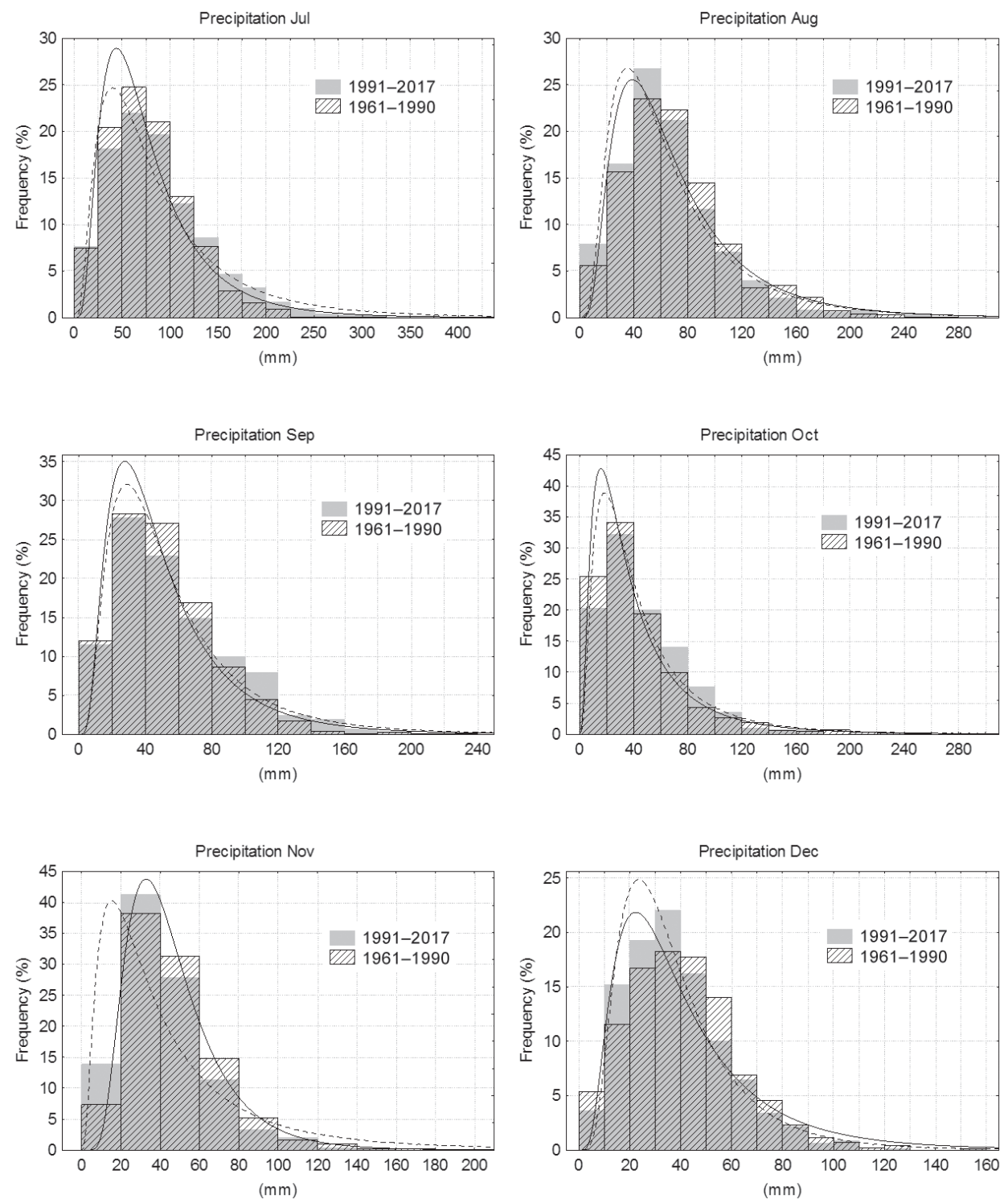

Fig. 11 (cont.) 
(1991-2017) is greater than for the earlier interval 1961-1990 for stations situated in the northern and central part of Poland as well as in the southern part, except for Kasprowy Wierch, but only four increases and one decrease are statistically significant. The mean change for all stations is $12.1 \%$. Increase in the winter precipitation total (DJF, 2.1\%) is due to an increase of January and February precipitation sums that outweigh the decrease in December. However, for six stations: Bielsko-Biała, Kalisz, Lublin, Rzeszów, Tarnów and Zakopane, despite of increase in precipitation total for January and February, the precipitation total for winter is decreasing, due to strong decreases in December. For other six stations: Kasprowy Wierch, Kielce, Opole, Racibórz, Sandomierz and Wieluń, precipitation total is decreasing for all winter months (in this, three changes are statistically significant).

March is the month with the largest percentage increase in precipitation total: for all stations, the average value reached $21.9 \%$ (see Table 2). At six out of 42 stations increasing changes are statistically significant (Fig 10d). The highest increase is found in Poznań (50\%) and for five other stations (Jelenia Góra, Koło, Leszno, Wrocław and Zielona Góra) the change is greater than $40 \%$. Only for three stations the change is negative. The first month of the vegetation season, April, is getting drier in the western part of Poland with four statistically significant decreases and a bit more humid in the eastern part of the country (Fig. 10e), but the mean change for all stations is decreasing: $-4.4 \%$ (Table 2). In May, one can observe positive changes in precipitation total over a large area of the country (with one significant change), except for south-western Poland, where changes are decreasing and statistically significant at four stations (Fig. 10f). The mean change for all stations is positive, $4.1 \%$ (Table 2). Despite of wetter March, spring is getting drier in south-western Poland (Figs. $8 \mathrm{~b}$ and $10 \mathrm{~d}-\mathrm{f}$ ).

Total precipitation in June decreases over a large area of Poland (34 stations therein four with significant changes). Only at seven stations located in the north of the country (with three changes being significant) and four in south-eastern and central Poland, increase in precipitation total is noted (Fig. 10g). The mean change for June is decreasing by $6.8 \%$. July is getting wetter at nearly all stations, especially in the west (Fig. 10h). The mean change for this month for all stations is $13.2 \%$. Among stations, the largest positive change is visible at Słubice (56\%, statistically significant change). In contrast, statistically insignificant decreases in precipitation total for this month can be observed in the north. In turn, precipitation total for August (Fig. 10i) decreases (with statistical significance in six cases) in central and southern Poland (above $30 \%$ in Opole). Precipitation increases (with one increase being statistically significant) mainly at north-western stations. The mean change for all stations is decreasing: $-5.7 \%$ (Table 2). Changes in precipitation sums for these three months contribute to the aggregate of $-0.2 \%$ : decrease in southern and central parts and increase in western and north-western parts of the country (Figs. $8 \mathrm{c}$ and 10g-i). 
Precipitation sum for September (Fig. 10j) increases more than for other autumn months, but only two changes are statistically significant. An increase was found at 39 stations and a decrease at six. The largest increase is in the southern and central part of Poland; small decrease is spotted in the north with one significant decrease according to Mann-Kendall (MK) test in Mława. Because of anomalously high precipitation total in September 2017 (163 mm; the highest value for the whole available period: 1961-2017 and higher by 235\% from the mean 1961-1990:49 mm), the percentage change is positive. The mean change for September is $10.9 \%$. October (Fig. 10k) is getting drier in west-central Poland and wetter in northern and south-eastern parts of the country (the most in Lesko, 28\%), but these changes are insignificant. The mean change for all stations is $7.1 \%$. Precipitation total for November (Fig. 101) decreases at 43 stations, therein 16 decreases are statistically significant, i.e. throughout nearly the whole area of Poland. The mean change for all stations is negative (by $-11.9 \%$ ) and is the highest among all of months. In result, precipitation sum for autumn decreases in central and northern parts and increases in south-eastern Poland (Figs. $8 \mathrm{~d}$ and $10 \mathrm{j}-1$ ).

Histograms for the monthly totals of precipitation for two intervals: 1961-1990 and 1991-2017 (Fig. 11) confirm the findings observed for monthly station data. The shift in relative frequency from lower to higher precipitation total is revealed the most for: March, February, then for July, September and October (for these months the changes in the mean are statistically significant), and for January, the least for May. For these months median and quartiles are higher for the last 27 years (1991-2017; Table 2). In turn, the shift in relative frequency from higher to lower precipitation total is observed the most for November, December, June, August (for these months the changes in means are statistically significant) and April. For these months, median and quartiles are lower for the last 27 years (1991-2017; Table 2).

\section{Discussion}

Presented results corroborate and update previous studies conducted for Poland and Europe. As EEA (2017) reported, there is a decreasing trend for gridded data of summer precipitation in south-eastern (exceeding $15 \mathrm{~mm} \mathrm{decade}^{-1}$ ) and central parts (from $10 \mathrm{~mm}$ decade $\mathrm{e}^{-1}$ to $0 \mathrm{~mm} \mathrm{decade}^{-1}$ ) of Poland and an increasing trend for summer precipitation in the northern part of the country (0-5 mm decade ${ }^{-1}$ ). This is in line with our study. Degirmendžić et al. (2004) noted a weak increasing trend of annual precipitation totals and of several monthly sums for period 1951-2000, but most of them were insignificant, except for March. Changes in annual precipitation were estimated to be less than $2 \%$ of the long-term annual average $(590 \mathrm{~mm})$, with decreasing contribution of summer precipitation sums 
(June-August) to the annual total. In turn, for 1958-2008, Degirmendžić and Kożuchowski (2017) identified insignificant decreasing trend in mean annual precipitation for Poland and also insignificant trends for seasons: decreasing for summer and spring and increasing for winter and autumn. Authors also analysed the mean intensity of total precipitation in Poland (not the same as SDII), which is decreasing for annual data. Czarnecka and Nidzgorska-Lencewicz (2012) studied seasonal precipitation total and the ratio of precipitation in Poland, based on data from 38 (without mountainous) stations for the period 1951-2010. According to their paper, over a large area of Poland, there is a slight increase in precipitation total during spring and autumn, while for winter and summer the numbers of stations with slight increase and decrease are nearly similar. Our research revealed larger changes in seasonal precipitation. There is a slight increase in winter precipitation and for spring precipitation the change in mean is statistically significant. Our findings are supported by Bhend and von Storch (2008), who presented trend in winter (DJF) precipitation totals in 1973-2002 in units of relative change compared to the 1961-1990 mean precipitation (based on the CRU TS 2.1 data) showing more humid northern part and drier south-western part of Poland. Mager, Kasprowicz, Farat (2009) examined data from 49 stations for 1966-2006 and showed an increasing tendency of mean annual precipitation total for some areas: south-eastern and north-western parts of Poland and decreasing tendency for the remaining area. According to these authors, winter and spring have been getting wetter, whereas summer and autumn - drier. These changes were due to higher precipitation in February, March and September. During June, October and November, authors noticed decrease in precipitation total. In this paper, with time series of observations extending to the year 2017, the mean percentage change of annual, as well as of winter, spring and autumn precipitation total and the mean percentage change of SDII show increases. Tomczyk and Szyga-Pluta (2018) analysed precipitation during the growing seasons in 1966-2015 and detected the increase of precipitation at most stations, but the change was statistically significant only in Świnoujście (22 $\mathrm{mm}$ decade $\mathrm{e}^{-1}$ ), like in our study for warm half-year.

Kaźmierczak, Kotowski, Wdowikowski (2014) detected a statistically insignificant decrease in annual precipitation total in 1954-2013 for four stations in the Odra basin: Legnica, Opole, Wrocław and Kłodzko. Moreover, an insignificant decrease in seasonal precipitation total for this area was noticed, what is in line with our observations. Świątek (2011), analysing 50-year series (1954-2003), detected a statistically significant increasing trend in precipitation totals for March in Szczecin, Koszalin, Łeba and Elbląg. This finding is partly supported by results for nearby regions. Hattermann et al. (2012) presented spatially irregular trend in mean annual precipitation in Germany. Increasing trend was reported in most of western Germany, while eastern Germany has decreasing trend in 1951-2006. In Czechia, Rulfová and Kyselý (2014) indicated increasing trends of 
total precipitation which prevail in all seasons except winter. Jaagus et al. (2018) analysed monthly, seasonal and annual precipitation totals for stations located in the eastern Baltic countries (Lithuania, Latvia, Estonia) for 1966-2015. They revealed increase in annual precipitation. Significant trends $(\mathrm{SL}<0.1)$ were observed on $42.1 \%$ of stations in Latvia, $36.8 \%$ in Estonia and $31.3 \%$ in Lithuania (17.7 mm, $12.5 \mathrm{~mm}$ and $7.1 \mathrm{~mm}$ per decade, respectively). For seasonal data, the highest increase (by approximately $10 \mathrm{~mm}$ per decade) was observed for winter precipitation, where significant trends were found at the most of stations. Also increasing, but weaker, trends were noticed during summer. For monthly precipitation, increases were detected at many stations in January, February and June. Decreasing trends were revealed at some stations in April and September. Avotniece et al. (2012) examined precipitation in Latvia in the interval 1950-2010, detecting a statistically significant increase in annual total precipitation in wet days (i.e with precipitation $\geq 1 \mathrm{~mm}$ ) and major changes in SDII. Tripolskaja and Pirogovskaja (2013) analysed precipitation totals for two stations: Vilnius in Lithuania and Minsk in Belarus for the interval 1987-2007 in comparison to 1961-1990 and stated that annual precipitation slightly increased (by $13 \mathrm{~mm}$ ) in Vilnius and strongly decreased in Minsk (by $109 \mathrm{~mm}$ ). For seasonal totals, a slight increase for Vilnius was noted only for winter, while for Minsk, precipitation totals decreased throughout all seasons; the most during summer. According to study conducted by Gera et al. (2017), annual and seasonal precipitation totals in Slovakia have not shown any significant trends for 1881-2016. During the cold half-year, a decreasing trend was found in southern Slovakia and an increasing trend in northern Slovakia. Additionally, a greater variability in the annual and seasonal totals and an increase of the convective precipitation have been observed since 1995. Zeleňáková et al. (2016) demonstrated a statistically significant increasing precipitation trend for 1981-2013 in Slovakia, during summer months (more than for 50\% of stations for July; nearly $9 \%$ for June) and during winter months (January: $22 \%$ of stations and December: $7 \%)$. December was the month with the highest number of stations with statistically significant decreasing trend: $3 \%$. Annual precipitation total was increasing for about $20 \%$ of stations. Boychenko et al. (2016) showed insignificant increase of annual precipitation total (5-7\% on 100 years) for interval 1885-2005 in Ukraine with decreases by $10-15 \%$ in northern and northwestern regions and increases by $10-15 \%$ in southern and southeastern regions. Decreases for the interval 1950-2000 are also noticed for seasonal and monthly precipitation: winter, spring (May), summer (August), autumn (October-November). Results of this study and those obtained by other authors show that the process of detection of trends in precipitation is more complex and indicate that the patterns of changes are less coherent in mid-latitude Europe. In contrast to strong anthropogenic warming trend, observed at global scale (IPCC 2013) as well as at regional and national scales (Klein Tank et al. 2005; Toll, Post 2017; Tomczyk 2017; Kożuchowski, Żmudzka 
2001; Wójcik, Miętus 2014; Graczyk et al. 2017; Wibig 2018), no straightforward explanation of identified trends in precipitation by anthropogenic climate change forcing is possible. An important factor impacting on the observed results is the natural variability of the precipitation process. Observed warming results in a reduced amount of solid precipitation (snow) and increase of liquid precipitation (rainfall; Taskinen, Söderholm 2016; Szwed et al. 2017). It may adversely impact winter tourism and also storage of water, because of higher and faster runoff that can led to the spring floods. According to analysis of time of floods in the northeast of Europe, Sweden, Finland and the Baltic region conducted by Blöschl et al. (2017), snowmelt floods nowadays occur one month earlier than in the 1960s and 1970s i.e. now in March. During warmer months, especially April, June and August, which have tendency to be drier, problems related to water deficit can get stronger.

Another issue is the distribution of precipitation during each month, i.e. intensity and amount of precipitation. Even if the monthly precipitation total is close to or above multi-year mean value, its distribution is uneven, especially during warm months (Rulfová, Kyselý 2014).

\section{Conclusions}

1. Changes in precipitation presented in this study in many cases are weak and statistically insignificant. For seasonal data, the highest number of statistically significant changes is noted for winter, the number of wet days and for summer. For monthly data, statistically significant changes are the most frequent for November and December (both only decreases) and for January and July (only increases).

2. Comparison of two periods: $1961-1990$ and 1991-2017, revealed that there is a shift in precipitation. Statistically significant changes in mean are observed for annual precipitation total, SDII, for spring precipitation total and for monthly precipitation totals in: February, March, July, September, October (in all cases there were increases) and June, August, November and December (decreases). It shows that monthly precipitation total can demonstrate different pattern, within a particular season.

3. Annual precipitation increased (though increase was mainly statistically insignificant), between 1961-1990 and 1991-2017 in northern, central and southeastern Poland and decreased over the area of upper and central Odra River basin.

4. Number of wet days with precipitation $\geq 1 \mathrm{~mm}$ decreased insignificantly in compared periods, mainly in southern and central Poland.

5. The value of SDII, as shown in this research, demonstrates increase, probably due to an increase of the amount of precipitation during wet days. 
6. The ratio of precipitation total in the warm season (Apr.-Sept.) to precipitation total in the cold season (Oct.-March) decreased (statistically insignificant change) and it is probably due to smaller increase of precipitation total for the warm half-year than for the cold half-year.

7. Seasonally, more precipitation in the later period (1991-2017) occurred during winter, spring and autumn and less in summer. Winter (DJF) in Poland became wetter for central and northern parts of the country and drier in southern part. During spring (MAM) precipitation total increased over nearly the whole country, except for the area of upper and central Odra River basin. For summer, decreases are prevailing and increases are observed only in western Poland. Precipitation total during autumn (SON) increased in eastern and southern Poland.

8. Higher monthly precipitation totals were observed in January, February, March, May, July, September and October. Lower precipitation totals were recorded during April, June, August, November and December.

9. Analyses of seasonal and monthly precipitation totals revealed a worrisome tendency - precipitation shifted from warmer to colder half-year. Even if one increase in precipitation totals in months from warm half-year can be observed, it can be insufficient, so that shortages of water during the (warmer) growing season may get worse. Additionally, this situation can be exacerbated by higher temperatures and heat waves.

\section{References}

AVOTNIECE, Z., KLAVINS, M., RODINOVS, V. (2012): Changes of extreme climate events in Latvia. Environmental and Climate Technologies, 9, doi: 10.2478/v10145-012-0010-1.

BECKER, A., FINGER, P., MEYER-CHRISTOFFER, A., RUDOLF, B., SCHAMM, K., SCHNEIDER, U., ZIESE, M. (2013): A description of the global land-surface precipitation data products of the Global Precipitation Climatology Centre with sample applications including centennial (trend) analysis from 1901-present. Earth Syst. Sci. Data. 5, 71-99, doi: https:// doi.org/10.5194/essd-5-71-2013.

BHEND, J., VON STORCH, H. (2008): Consistency of observed winter precipitation trends in northern Europe with regional climate change projections. Clim Dyn., 31, 1, 17-28, doi:10.1007/s00382-007-0335-9.

BLÖSCHL, G., HALL, J., PARAJKA, J., PERDIGÃO, R.A.P., MERZ, B., ARHEIMER, B., ARONICA, G.T., BILIBASHI, A., BONACCI, O., BORGA, M., CANJEVAC, I., CASTELLARIN, A., CHIRICO, G., B., CLAPS, P., FIALA, K., FROLOVA, N., GORBACHOVA, L., GÜL, A., HANNAFORD, J., HARRIGAN, S., KIREEVA, M., KISS, A., KJELDSEN, T.R., KOHNOVÁ, S., KOSKELA, J.J., LEDVINKA, O., MACDONALD, N., MAVROVA-GUIRGUINOVA, M., MEDIERO, L., MERZ, R., MOLNAR, P., MONTANARI, A., MURPHY, C., OSUCH, M., OVCHARUK, V., RADEVSKI, I., ROGGER, M., SALINAS, J.L., SAUQUET, E., SRAJ, M., SZOLGAY, J., VIGLIONE, A., VOLPI, E., WILSON, D., ZAIMI, K., ZIVKOVIC, N. (2017): Changing climate shifts timing of European floods. Science, 357, 6351, 588-590, doi:10.1126/ science.aan2506. 
BOYCHENKO, S., VOLOSHCHUK, V. MOVCHAN, Y., SERDJUCHENKO, N., TKACHENKO, V., TYSHCHENKO, O., SAVCHENKO, S. (2016): Features of climate change on Ukraine: Scenarios, consequences for nature and agroecosystems. Proceedings of the National Aviation University. 4, 69, 96-113, doi 10.18372/2306-1472.69.11061.

CZARNECKA, M., NIDZGORSKA-LENCEWICZ, J. (2012): Wieloletnia zmienność sezonowych opadów w Polsce. Woda-Środowisko-Obszary Wiejskie, 12, 2, 38, 45-60.

DEGIRMENDŽIĆ, J., KOŻUCHOWSKI, K., ŻMUDZKA, E. (2004): Changes of air temperature and precipitation in Poland in the period 1951-2000 and their relationship to atmospheric circulation. International Journal of Climatology, 24, 3, 291-310.

DEGIRMENDŽIĆ, J., KOŻUCHOWSKI, K. (2017): Mediterranean cyclones, the Atmospheric Moisture Content and precipitation in Poland. Geographia Polonica, 90, 1, 5-20, https://doi. org/10.7163/GPol.0075.

DONAT, M.G., ALEXANDER, L.V., YANG, H., DURRE, I., VOSE, R., DUNN, R.J.H., WILLETT, K.M., AGUILAR, E., BRUNET, M., CAESAR, J., HEWITSON, B., JACK, C., KLEIN TANK, A.M.G., KRUGER, A.C., MARENGO, J., PETERSON, T.C., RENOM, M., ORIA ROJAS, C., RUSTICUCCI, M., SALINGER, J., ELRAYAH, A.S., SEKELE, S.S., SRIVASTAVA, A.K., TREWIN, B., VILLARROEL, C., VINCENT, L.A., ZHAI, P., ZHANG, X., KITCHING, S. (2013): Updated analyses of temperature and precipitation extreme indices since the beginning of the twentieth century: The HadEX2 dataset. J. Geophys. Res. Atmos. 118, 2098-2118, doi:10.1002/jgrd.50150.

EEA (2017): Report of European Environment Agency. http://www.eea.europa.eu/data-andmaps/figures/observed-changes-in-annual-precipitation-1961-6 (18.5.2018).

GERA, M. DAMBORSKA, I. LAPIN, M., MELO M. (2017): Climate Changes in Slovakia: Analysis of Past and Present Observations and Scenarios of Future Developments. In: Negm, A.M. Zeleňáková, M. (eds.): Water Resources in Slovakia: Part II - Climate Change, Drought and Floods, Hdb Env Chem, Springer, doi: 10.1007/698_2017_157.

GRACZYK, D., PIŃSKWAR, I., KUNDZEWICZ, Z.W., HOV, Ø., FøRLAND, E.J., SZWED, M., CHORYŃSKI, A. (2017): The heat goes on - changes in indices of hot extremes in Poland. Theor. Appl. Climatol. 129, 459, doi.org/10.1007/s00704-016-1786-x.

GUS (2016): Environment 2016. Central Statistical Office, Warsaw, www.stat.gov.pl.

HATTERMANN, F.F., KUNDZEWICZ, Z.W., HUANG, S., VETTER, T., KRON, W., BURGHOFF, O., MERZ, B., BRONSTERT, A., KRYSANOVA, V., GERSTENGARBE, F.W., WERNER, P., HAUF, Y. (2012): Floods risk from a holistic perspective - Observed changes in Germany. In: Kundzewicz, Z.W. (ed.): Changes in Flood Risk in Europe. Special Publication No. 10, IAHS Press, Wallingford, Oxfordshire, 212-237.

IMGW (2018): State of the 2018 drought, http://www.imgw.pl/2018/10/11/susza-2018-podsumowanie-okresu-wegetacyjnego/ (22.3.2019).

IPCC (2013): Climate Change 2013: The Physical Science Basis. Contribution of Working Group I to the Fifth Assessment Report of the Intergovernmental Panel on Climate Change. Stocker, T.F., Qin, D., Plattner, G.-K., Tignor, M., Allen, S.K., Boschung, J., Nauels, A., Xia, Y., Bex, V., Midgley, P.M. (eds.) Cambridge University Press, Cambridge, UK.

JAAGUS, J., BRIEDE, A., RIMKUS, E., SEPP, M. (2018): Changes in precipitation regime in the Baltic countries in 1966-2015. Theor Appl Climatol, 131, 433, https://doi.org/10.1007/ s00704-016-1990-8.

KAŹMIERCZAK, B., KOTOWSKI, A., WDOWIKOWSKI, M. (2014): Analiza tendencji rocznych i sezonowych zmian wysokości opadów atmosferycznych w dorzeczu Górnej Odry. Ochrona Środowiska, 36, 3, 49-54. 
KĘDZIORA, A., KĘPIŃSKA-KASPRZAK, M., KOWALCZAK, P., KUNDZEWICZ, Z.W., MILER, A.T., PIERZGALSKI, E., TOKARCZYK, T. (2014): Zagrożenia związane z niedoborem wody. Nauka, 2014, 1, 149-172.

KLEIN TANK, A.M., G., KÖNNEN, G.P., SELTEN, F.M. (2005): Signals of anthropogenic influence on European warming as seen in the trend patterns of daily temperature variance. Int. J. Climatol. 25, 1-16.

KONIECZNY, R., PIŃSKWAR, I., KUNDZEWICZ, Z.W. (2018): The September 2017 flood in Elbląg (Poland) in perspective. Meteorol. Hydrol. Water Manage, 6, 2, 67-78.

KOVATS, R.S., VALENTINI, R., BOUWER, L.M., GEORGOPOULOU, E., JACOB, D., MARTIN, E., ROUNSEVELL, M., SOUSSANA, J.-F. (2014): Europe. In: Barros, V.R., Field, C.B., Dokken, D.J., Mastrandrea, M.D., Mach, K.J., Bilir, T.E., Chatterjee, M., Ebi, K.L., Estrada, Y.O., Genova, R.C., Girma, B., Kissel, E.S., Levy, A.N., Maccracken, S., Mastrandrea, P.R., White, L.L., eds.: Climate Change 2014: Impacts, Adaptation, and Vulnerability. Part B: Regional Aspects. Contribution of Working Group II to the Fifth Assessment Report of the Intergovernmental Panel on Climate Change. Cambridge University Press, Cambridge, United Kingdom and New York, NY, USA, 1267-1326.

KOŻUCHOWSKI, K. (2004): Zmienność opadów atmosferycznych w Polsce w XX i XXI wieku. In: Kożuchowski, K. (ed.): Skala, uwarunkowania i perspektywy współczesnych zmian klimatycznych w Polsce. Wyd. Biblioteka, Łódź, 47-57.

KOŻUCHOWSKI, K., ŻMUDZKA, E. (2001): Ocieplenie w Polsce, skala i rozkład sezonowy zmian temperatury powietrza w drugiej połowie XX wieku. Przegl Geofiz. XLVI, 1-2, 81-90. KUNDZEWICZ, Z.W., DOBROWOLSKI, A., LORENC, H., NIEDŹWIEDŹ, T., PIŃSKWAR, I., KOWALCZAK, P. (2012): Floods in Poland. In: Kundzewicz, Z.W. (ed.): Changes in Flood Risk in Europe, Special Publication No. 10, IAHS Press, Wallingford, Oxfordshire, UK., Ch. 17, 319-334.

ŁUPIKASZA, E. (2017): Seasonal patterns and consistency of extreme precipitation trends in Europe, December 1950 to February 2008. Clim Res., 72, 217-237, doi.org/10.3354/cr01467.

MAGER, P., KASPROWICZ, T., FARAT, R. (2009): Change of air temperature and precipitation in Poland in 1966-2006. In: Leśny, J. (ed.): Climate change and agriculture in Poland - impacts, mitigation and adaptation measures. Acta Agrophysica. Rozprawy i Monografie, 169, 1, 19-38.

PIŃSKWAR, I., CHORYŃSKI, A., GRACZYK, D., KUNDZEWICZ, Z.W. (2019): Observed changes in extreme precipitation in Poland: 1991-2015 versus 1961-1990. Theor Appl Climatol. 135, 773, https://doi.org/10.1007/s00704-018-2372-1.

RULFOVÁ, Z., KYSELÝ, J. (2014): Trends of convective and stratiform precipitation in the Czech Republic, 1982-2010. Advances in Meteorology, 647938, 11, https://doi.org/10.1155/2014/647938.

SOMOROWSKA, U. (2016): Changes in drought conditions in Poland over the past 60 years evaluated by the Standardized Precipitation-Evapotranspiration Index. Acta Geophys. 64, 2530-2549, doi: 10.1515/acgeo-2016-0110.

ŠTĚPÁNEK, P. (2008): AnClim - software for time series analysis: Dept. of Geography, Fac. of Natural Sciences, MU, Brno, http://www.climahom.eu/AnClim.html (5.6.2017).

SZWED, M., PIŃSKWAR, I., KUNDZEWICZ, Z.W., GRACZYK, D., MEZGHANI, A. (2017): Changes of snow cover in Poland. Acta Geophys. 65, 65-76, doi.org/10.1007/s11600-0170007-z.

ŚWIĄTEK, M. (2011): Precipitation changes on the Polish coast of the Baltic Sea (1954-2003) due to changes in intensity of westerlies over Europe. Clim Res, 48, 23-29, doi: 10.3354/cr00904.

TASKINEN, A., SÖDERHOLM, K. (2016): Operational correction of daily precipitation measurements in Finland. Boreal Env. Res. 21, 1-24. 
TOLL, V., POST, P. (2017): Daily temperature and precipitation extremes in the Baltic Sea region derived from the BaltAn65+ reanalysis. Theor Appl Climatol., doi.org/10.1007/s00704-0172114-9.

TOMCZYK, A.M. (2017): Atmospheric circulation during heat waves in Eastern Europe. Geografie, 122, 2, 121-146.

TOMCZYK, A.M., SZYGA-PLUTA, K. (2018): Variability of thermal and precipitation conditions in the growing season in Poland in the years 1966-2015. Theor Appl Climatol., https:// doi.org/10.1007/s00704-018-2450-4.

TRIPOLSKAJA, L., PIROGOVSKAJA, G. (2013): Impact of climate variability in Lithuania and Belarus on atmospheric precipitation infiltration: lysimetric study. Zemdirbyste-Agriculture, 100, 4, 369-376, doi: 10.13080/z-a.2013.100.047.

WESTRA, S., ALEXANDER, L.V., ZWIERS, F.W. (2013): Global increasing trends in annual maximum daily precipitation. J. Clim., 26, 3904-3918.

WIBIG, J. (2018): Heat waves in Poland in the period 1951-2015: trends, patterns and driving factors. Meteorol. Hydrol. Water Manage. 6, 1, 37-45, doi.org/10.26491/mhwm/78420.

WIBIG, J., JAKUSIK E., eds. (2012): Warunki klimatyczne i oceanograficzne w Polsce i na Bałtyku południowym - spodziewane zmiany i wytyczne do opracowania strategii adaptacyjnych w gospodarce krajowej. T.1, IMGW-PIB, Warszawa.

WIJNGAARD, J.B., KLEIN TANK, A.M.G., KONNEN, G.P. (2003): Homogeneity of $20^{\text {th }}$ century European daily temperature and precipitation series. Int. J. Climatol. 23, 679-692.

WÓJCIK, R., MIĘTUS, M. (2014): Niektóre cechy wieloletniej zmienności temperatury powietrza w Polsce (1951-2010). Prz. Geol., 86, 3, 339-364.

ZELEŇÁKOVÁ, M., PURCZ, P., POÓROVÁ, Z., ALKHALAF, I., HLAVATÁ, H., PORTELA, M.M. (2016): Monthly trends of precipitation in gauging stations in Slovakia. Procedia Engineering, 162, 106-111, https://doi.org/10.1016/j.proeng.2016.11.023.

ZHANG, X., ALEXANDER, L., HEGERL, G.C., JONES, P., KLEIN TANK, A., PETERSON, T.C., TREWIN, B., ZWIERS, F.W. (2011) Indices for monitoring changes in extremes based on daily temperature and precipitation data. WIREs Clim Change, doi: 10.1002/wcc.147.

\section{ACKNOWLEDGEMENTS}

This research was supported by the project CHASE-PL (Climate change impact assessment for selected sectors in Poland) of the Polish-Norwegian Research Programme under the Norwegian Financial Mechanism 2009-2014 in the frame of Project Contract No. Pol Nor/200799/90/2014. Two anonymous referees are acknowledged for their valuable comments. 